\title{
Incentive to Retrench? Investigating the Interactions of State and Federal Social Assistance Programs after Welfare Reform
}

\author{
Zachary Parolin \\ University of Antwerp \\ Christiaan Luigjes \\ University of Amsterdam
}

Preprint of publication accepted at Social Service Review

\begin{abstract}
$^{1}$
Spending on cash assistance from the Temporary Assistance for Needy Families (TANF) program has declined across the U.S. throughout recent decades. Simultaneously, spending on the federally-funded Supplemental Nutrition Assistance Program (SNAP) and Supplemental Security Income (SSI) programs has steadily increased. This papers investigates whether retrenchment of TANF assistance has led to increases in the participation and levels of benefit receipt of SNAP and SSI. Applying a differences-in-differences approach on household income data from 1997 to 2015 , we find that a $\$ 50$ policy-induced decline in states' TANF cash assistance allocations leads to an increase of between $\$ 17$ to $\$ 32$ per month in federal allocations of SNAP and SSI benefits among single-mother households. From a household income perspective, these findings suggest that increases in SNAP and SSI participation have partially offset the retrenchment in TANF assistance. From a state incentive perspective, we find that state governments have the ability, and even a financial incentive, to shift social assistance caseloads to the federal government.
\end{abstract}

Keywords: program interaction; Temporary Assistance for Needy Families; Supplemental Security Income; Supplemental Nutritional Assistance Program; social policy; federalism

\section{Corresponding Author:}

Zachary Parolin

Herman Deleeck Centre for Social Policy, University of Antwerp

2 Sint-Jacobsstraat

2000 Antwerp, Belgium

Zachary.Parolin@UAntwerpen.be

\footnotetext{
${ }^{1}$ For comments and feedback, the authors are grateful to Bea Cantillon, Johan De Deken, Frank Vandenbroucke, Michael Wiseman, three anonymous reviewers, participants of the Herman Deleeck Centre for Social Policy seminar series, and members of the Young PETGOV discussion group at the University of Amsterdam.
} 


\section{Introduction}

The decline of cash assistance has been a large focus of American poverty and policy research from 1996 onward. After welfare reform and the introduction of the state-administered Temporary Assistance for Needy Families (TANF) program, the provision of cash assistance has steadily declined across all states. Simultaneously, however, spending on two federallyfunded social transfer programs - Supplemental Nutrition Assistance Program (SNAP, or 'food stamps') and Supplemental Security Income (SSI, a means-tested income supplement targeted at blind, disabled, and/or older-age adults) - has increased throughout the past two decades. This paper investigates the relationship of these divergent trends. Specifically, we investigate the extent to which retrenchment of state-administered TANF cash assistance has led to increases in participation and levels of household benefit receipt of the federally-funded SNAP and SSI programs.

We emphasize two perspectives on why an investigation into the interactions of the TANF, SNAP, and SSI programs is necessary. From a household income perspective, this analysis of program interaction places the social consequences of TANF's decline in the context of growing SNAP and SSI caseloads. The decrease of TANF cash assistance from 1997 onward has been cited as a key contributor to rising poverty rates over time and differences in poverty rates between states (Edin and Shaefer, 2016; Parolin, 2018). Less clear, however, is whether and how retrenchment in TANF cash assistance has affected participation levels and benefit values of SNAP and SSI. Economic theories of program participation suggest that declining generosity of TANF would increase the relative incentive for an eligible household to pursue SNAP or SSI benefits (Keane and Moffitt, 1998). Moreover, declines in TANF benefit levels may have a mechanical effect on the level of SNAP benefits among households receiving both. To what extent, then, has TANF retrenchment led to increases in benefit allocations of SNAP and SSI? And to what extent have gains in SNAP and SSI allocations offset TANF's decline? 
From a state incentive perspective, this analysis reveals whether state governments can shift the burden of cash assistance to the federal government through a retrenchment in TANF assistance. Prior to the introduction of TANF, the federal government matched at least 50 percent of states' allocations of cash assistance for low-income families; thus, an increase in state expenditures on cash assistance would directly lead to an equal or larger increase in federal expenditures. In response to rapidly rising cash assistance caseloads, policymakers introduced a 'block grant' funding structure to cap the annual amount of federal spending and simultaneously provide states more flexibility in administering social assistance funds. While the block grant severed the direct link between fluctuations in TANF caseloads and federal costs, the flexibility granted to the states may provide them opportunities to influence federal spending on other social programs, such as SNAP and SSI. Moreover, we demonstrate that the structure of the TANF block grant plausibly provides state governments a financial incentive to cut back on the generosity of TANF benefits. Spending less on cash assistance allows states to reallocate the preserved TANF funds to supplant non-TANF state expenditures, such as foster care services, childcare assistance, wage subsidies, and other policy areas that might otherwise be funded through general state revenues.(Germanis, 2015; Chernick, 2000).

Our findings shed light on each of these inquiries and contribute to American welfare state literature in three primary ways. First, we utilize a novel methodological approach to clarify the relationship between the decline in TANF and the rise of SNAP and SSI. Using household-level data on TANF, SNAP, and SSI participation and benefit receipt from 1997 to 2015, we apply a variation of a differences-in-differences method to capture the effects of policy-induced changes in TANF benefit allocations on changes in SNAP and SSI allocations. Acknowledging the issue of underreporting of benefit receipt in household income data, we perform our analysis on a version of the Current Population Survey (CPS ASEC) that adjusts for underreporting of SNAP, TANF, and SSI. As sensitivity checks, however, we also present 
results based on the unadjusted version of the CPS ASEC and on microdata from SNAP Quality Control reports.

Second, we clarify the extent to which SNAP and SSI have offset the decline of TANF benefit generosity for the average single-mother household. Our primary findings suggest a $\$ 50$ per month policy-induced decline in a state's TANF cash assistance allocations leads to an increase of between $\$ 17$ to $\$ 32$ per month in federal SNAP and SSI allocations. In other words, the federal government has plausibly filled in for around half of states' retrenchment in TANF benefit generosity. From a household income perspective, the decline of TANF still leads to a net loss in total provision of social assistance, but our findings show that the overall decline of social assistance from the mid-1990s onward is perhaps less severe than a focus purely on TANF would suggest.

Finally, our findings suggest that the structure of TANF and the interaction among the three social assistance programs plausibly provides state governments a financial incentive to cut back on TANF assistance. Not only can states shift the burden of social assistance to the federal government, but they can then reallocate the recouped TANF funds toward programs and services that might otherwise be funded with general state revenues.

\section{Background \& Theory}

\section{The Decline of TANF}

The legislation that introduced TANF transformed three core components of stateadministered social assistance. First, it strengthened the conditionality requirements attached to the receipt of cash assistance. Under Aid to Families with Dependent Children (AFDC), the predecessor program to TANF, families under a certain income threshold were entitled to cash support. With the introduction of TANF, however, that entitlement was ended and recipients would be required to engage in 'work participation activities' or employment to continue 
receiving cash support beyond a certain duration (Falk, 2014). Second, the legislation expanded the scope of the program's objectives. While AFDC was primarily a cash assistance program, TANF funds can be allocated to any of the program's four statutory purposes: "to provide assistance to needy families," "to end the dependence of needy parents on government benefits by promoting job preparation, work, and marriage," "to prevent and reduce the incidence of out-of-wedlock pregnancies," and "to encourage the formation and maintenance of two-parent families". ${ }^{2}$ Third, TANF replaced the open-ended federal matching scheme with non-indexed block grants and a mandatory 'Maintenance of Effort' (MOE) requirement (a level of expenditures that states must commit to the program) (Falk, 2016). Ending the federal-state match ensured that states would "no longer have the promise of increased federal funds as an incentive for greater outlays of state dollars" (Hoke, 1998: 128). As we will describe, however, the combination of these three changes may still allow states to induce greater levels of federal expenditures.

Since the implementation of TANF, caseloads have consistently declined. During the same timeframe (1997 to 2015), caseloads for the federally-funded SNAP and SSI programs have increased. Figure 1 depicts the trends in participation rates among the three benefits from 1997 onward among households headed by a single mother without a college degree (age 1844) - the primary target and beneficiary of the TANF program. TANF caseloads have fallen from about 23 percent of single mothers in 1997 to around 7 percent in 2015. By 2015, the share of single mothers participating in the SSI program had converged with the share receiving cash support from TANF. ${ }^{3}$ The participation rate of single-mother households in SNAP steadily increased until 2008, then experienced a sharp rise from 2008 onward due to an expansion of

\footnotetext{
${ }^{2}$ The Personal Responsibility and Work Opportunity Reconciliation Act, 42 U.S.C. $§ 601$ (1996).

${ }^{3}$ Both child and adult blind/disabled SSI cases have increased from 1997 onward. However, the age composition of the cases is roughly the same in 2015 as it was in 1997: around 22 percent of blind/disabled SSI cases are child cases, whereas around 78 percent are adult/elderly cases (Social Security Administration, 2017). As we measure benefit receipt at the household level, the distinction of whether the single mother or her child is being awarded SSI benefits is not necessary within the context of this paper.
} 
benefits and an increase in demand for social assistance after the onset of the economic recession. $^{4}$

\section{[INSERT FIGURE 1 ABOUT HERE]}

A central focus of this paper is to understand the extent to which these diverging trends in declining TANF assistance versus rising SNAP and SSI assistance are related. Specifically, we investigate how the decisions of state policymakers to cut back on the generosity of TANF cash assistance contribute to participation and levels of benefit receipt of the federally-funded SNAP and SSI.

\section{The Interactions of TANF, SNAP \& SSI}

Prior research has provided mixed evidence on the interactions between TANF and SSI, as well as between TANF and SNAP. While each is targeted toward low-income households, the programs feature different eligibility criteria, types of support provided, and mechanisms for overlap or interaction.

The federally-funded SNAP, or 'food stamps', serves low-income families with benefits earmarked for food and some basic necessities. Though each state administers the provision of its own SNAP benefits, SNAP is different from the state-run TANF program in that its benefit calculation procedures are set at the federal level. SNAP interacts with TANF in regard to eligibility and benefit levels. Most straightforwardly, nearly all recipients of TANF cash assistance are 'categorically eligible' for SNAP assistance. Categorical eligibility implies that a person is eligible for SNAP on the basis of receipt of other specified means-tested transfers,

\footnotetext{
${ }^{4}$ These patterns of participation rates mirror overall expenditures on the three programs in 2014: SNAP benefits reached nearly $\$ 70$ billion in 2014, while SSI payments (toward all family types) reached \$55 billion and TANF expenditures reached $\$ 32$ billion, around $\$ 8$ billion of which were allocated to cash assistance.
} 
such as TANF (see Moffitt (2015) for a detailed discussion). While the majority of TANF beneficiaries are also SNAP beneficiaries, the reverse is not true: eligibility for SNAP does not grant access to TANF benefits, and most SNAP beneficiaries do not receive TANF cash assistance (Klerman and Danielson, 2011). As Figure 1 shows, more than half of single-mother households within the sample received SNAP assistance in 2015, while only around 7 percent received TANF cash support. Though economic circumstances, such as the rise of unemployment beginning in 2008, account for the bulk of increasing SNAP participation in recent years, policy changes to TANF and SNAP also appear to contribute to the divergent patterns in Figure 1 (Blank, 2002; Grogger et al., 2002; Ganong and Liebman, 2018; Ziliak, 2015). As states' TANF policies have become more restrictive, accessibility to SNAP has, in nearly all states, been made easier through modifications of asset limits, reporting requirements, and the duration of recertification periods (Klerman and Danielson, 2011).

Additionally, the expansion of categorical eligibility may contribute to the number of SNAP-without-TANF cash assistance cases. In 2001, the introduction of 'broad-based categorical eligibility' (BBCE) meant that even households in which at least one person receives noncash TANF services would be eligible for SNAP benefits (Falk and Aussenberg, 2014). The majority of states have since chosen to implement some form of BBCE, which can extend SNAP eligibility to families through a mechanism as simple as offering a brochure or the availability of a telephone hotline (Falk and Aussenberg, 2014). A federal audit concluded that BBCE practices accounted for 2.6 percent of the total SNAP caseload during the Great Recession (U.S. General Accounting Office, 2012), while Ganong and Liebman (2018) estimate that BBCE increased SNAP enrollment by around 1.6 million persons by 2011 .

A relationship may also exist between TANF and SNAP benefit levels among households receiving both. The level of SNAP benefits that an eligible household receives is inversely related to its 'net monthly family income.' TANF benefits are included in this 
definition of net income. Thus, lowering TANF benefits for a family that also receives SNAP may entail an increase in SNAP benefit levels (Center on Budget \& Policy Priorities, 2017; Schmidt et al., 2016). This interaction remains unexplored in much of prior program interaction research, but is assessed in our analyses as a potential mechanism for states to induce greater levels of federal benefit allocations through a decrease in TANF generosity.

The extent of interaction between TANF and federally-funded SSI, meanwhile, is also contested. While SSI also provides cash assistance, its eligibility criteria are far more limiting than those of TANF or SNAP: SSI provides assistance for the low-income elderly, blind and/or disabled. ${ }^{5}$ Nonetheless, prior studies have suggested that declining AFDC/TANF participation may be associated with an increase in SSI participation. Even before welfare reform, state governments had an incentive to shift eligible low-income households from AFDC to the more generous SSI program (Schmidt and Sevak, 2004; Kubik, 2003). The incentives for eligible households to shift to SSI appeared to intensify after welfare reform, as the transition to TANF made cash assistance "less attractive for single mothers" (Schmidt and Sevak, 2004). Wiseman and Wamhoff (2006) also observe that TANF strengthened the financial gains for states and low-income households to transition from TANF to SSI, a practice which the federal government actively encourages (Farrell, 2013). It is plausible that the extent to which TANF to SSI transitions are possible varies across states. States with larger shares of residents experiencing adverse health outcomes, for example, would plausibly have an easier time shifting TANF caseloads to SSI.

Some empirical evidence exists to support the TANF-SSI interaction effect: Schmidt (2012), Schmidt (2004), and Bound et al. (1998), for example, find that less generous state-run

\footnotetext{
${ }^{5}$ It is unclear as to the extent of eligible TANF households that may also be eligible for SSI. A 2009 study showed that over a quarter of TANF recipients between 22 and 55 years reported some physical, mental or emotional problem that limits their work capacity (Loprest \& Maag, 2009); whether such ailments translate into SSI eligibility is often a subjective decision made by ground-level health professionals and SSI administrators. Only three percent of single parent households in our 2015 sample received both TANF and SSI benefits.
} 
social assistance programs (AFDC and/or General Assistance) are associated with higher levels of SSI participation. Similarly, Garrett and Glied (2000) provide evidence that families tend to use SSI benefits and cash assistance from AFDC as substitutes. Others, however, have casted doubt on the extent to which SSI-TANF transitions occur. In a study of administrative records across 26 states, for example, Skemer and Bayes (2013) find scant evidence to support the claim that TANF beneficiaries transfer over to SSI.

This paper attempts to add empirical and conceptual clarity to the mixed or incomplete evidence on the relationships between TANF and SNAP/SSI in prior research. From a methodological perspective, we follow Schmidt and Sevak (2004) in moving beyond the use of state- or group-level means as dependent variables, which introduces greater possibility for measurement error (as differences in the demographic characteristics of the population across states and years can less adequately be controlled) and disallows for evaluation of how demographic features affect the likelihood of program interaction. Schmidt (2012), Garrett and Glied (2000), and Kubik (2003), for example, use state-year means of program participation as their outcome variables, while Klerman and Danielson (2011) operationalize clusters of program participants within state-years. We instead use household-level data and include a robust set of demographic controls to more appropriately account for differences in the composition of each state-year's population and to measure the effects of demographic characteristics on TANF, SSI, and SNAP participation. Conceptually, we place the interaction of the three social assistance programs in the context of household and state government incentive structures, which we now describe in more detail.

\section{Conceptual Framework}

Our primary hypothesis states that a reduction in a state's generosity of TANF cash assistance leads to increases in SNAP and SSI benefit allocations within the state. With respect to the relationship between TANF and SSI, our hypothesis rests on the economic theory of 
program participation (Klerman and Danielson, 2011; Keane and Moffitt, 1998). Specifically, we expect that the average single mother will evaluate the employment and social assistance opportunities available to her and act in a way that maximizes utility. Thus, a decline in the generosity of states' TANF benefits relative to SSI benefits should increase the likelihood that the single mother, if eligible, will pursue SSI benefits. With respect to the relationship between TANF and SNAP, we expect to observe a mechanical benefit substitution. Recall that a decline in the value of TANF benefits that a household receives is likely to increase the level of SNAP benefits for which a single mother is eligible.

Together, these individual- or household-level responses to declining TANF generosity then translate into our expected relationships at the state level: declines in TANF cash assistance generosity will be associated with increases in federal allocation of SNAP and SSI benefits. If the evidence corroborates our hypothesis, we can further conceptualize its ramifications in the contexts of the economic security of low-income households and the incentives facing state governments.

From a household income perspective, an analysis of program interaction places the social consequences of TANF's decline in the context of rising SNAP and SSI participation rates. Retrenchment of TANF has been cited as a central contributor to rising levels of poverty, and 'extreme' poverty in particular (Edin and Shaefer, 2016; Danziger et al., 2012). Given the rise of SNAP (as well as SSI) caseloads, however, to what extent has TANF's decline merely represented a shift from state-administered to federally-funded social transfer programs? ${ }^{6}$ More specifically, to what extent is TANF retrenchment associated with increases in federal allocations of SNAP and SSI benefits?

\footnotetext{
${ }^{6}$ The pervasive practice in income measurement today is to include SNAP benefits into measurements of disposable household income (LIS, 2016; Short, 2012; Smeeding and Rainwater, 2001). See Beatty and Tuttle (2014) and Hoynes, Schanzenbach, and Whitmore (2009) for evidence on the substitutability of SNAP and cash income.
} 
From a state incentive perspective, evidence supporting our hypothesis would indicate an ability of state governments to shift the burden of cash assistance to the federal government through a retrenchment in TANF cash assistance. Given the broad range of purposes toward which states can allocate TANF funds, corroboration of our hypothesis would also suggest that state governments experience a financial incentive to cut back on cash assistance. As states' TANF budgets are largely static over time (the federally-funded block grant is set at a fixed value, and many states' MOE spending tends not to fluctuate much over time), any retrenchment in TANF cash assistance allocations frees up funds that can be allocated toward other categories of policies and programs allowed under TANF's broad mandate (Germanis, 2015; Kubik, 2003; Chernick, 2000).

\section{Data \& Methods}

Our analytical approach estimates the effect of differences in the generosity of states' TANF benefits on participation rates and observed levels of benefit receipt of TANF, SNAP, and SSI. We use household income data from the Current Population Survey March Annual Social and Economic Supplement (CPS ASEC). The data cover each year from 1997 to 2015 — the first year of TANF implementation to the most recent year for which data on all variables is available. ${ }^{7}$ We limit our sample to households headed by single women without a college degree between the ages of 18 and $44(n=117,219)$. This includes non-married women who are cohabitating with another unrelated adult. ${ }^{8} \mathrm{We}$ are primarily interested in the interactions of TANF, SNAP, and SSI among single-mother households, as this is the family type most likely

\footnotetext{
${ }^{7}$ As detailed later, we apply TRIM3 benefit imputations to the CPS ASEC in our primary analysis to adjust for underreporting. The latest year of TRIM3 data at time of writing is reference year 2015 (2016 CPS ASEC), hence our end point. Performing our analyses on the unadjusted CPS data while adding in the latest two years of data (reference years 2016 and 2017) does not meaningfully alter our results.

${ }^{8}$ In sensitivity checks, we find that dropping cohabitating couples from our analysis does not meaningfully affect the results. The results are also robust to expanded age brackets (18-55 and 18-65 years old).
} 
to received means-tested transfers. As we explain below, however, we include single women without children into the sample to provide a comparison group in our estimation strategy.

We apply a variation of the differences-in-differences (DD) method to evaluate the effects of policy-induced changes in TANF generosity on our outcomes variables (SNAP, SSI, and TANF participation and observed levels of household benefit receipt). A standard DD model compares the effects of a change in policy on a treatment group (those whom the policy change affects) and a control group; thus, the method is most appropriate when there is a single policy change or treatment event. With respect to TANF, however, many policy changes have occurred across the 50 states at different times throughout the past two decades.

To fully account for these changes across time and place, we follow Hoynes and Luttmer (2010) and Hoynes and Patel (2015), among others, in constructing a 'simulated' TANF generosity variable that captures changes in TANF generosity across year, state, and household size. The intent of the simulated TANF variable is to provide a single indicator that reflects policy-induced changes in TANF generosity within states over time, independent of demographic or other compositional changes that may occur within the population. Different from a standard DD model, this treatment variable is continuous (non-binary). A similar method has been used in prior research to estimate the effects of policy-induced changes in the Earned Income Tax Credit, income tax brackets, healthcare expansion, and other social assistance programs (Cutler and Gruber, 1996; Eissa and Hoynes, 2004; Hoynes and Patel, 2015; Milligan and Stabile, 2011; Schmidt et al., 2016; Jones and Michelmore, 2016).

We estimate the effect of policy-induced changes in TANF generosity on TANF, SSI, and SNAP participation rates and household benefit levels as follows:

$$
\mathrm{y}_{\mathrm{istf}}=\beta_{0}+\beta_{1} \text { TANFGen }_{\text {stf }}+\beta_{2} \mathrm{X}_{\mathrm{i}}+\beta_{3} \alpha_{\mathrm{st}}+\delta_{\mathrm{s}}+\gamma_{\mathrm{t}}+\lambda_{\mathrm{f}}+\varepsilon_{\mathrm{i}}
$$

where $i$ indexes individuals, $s$ indexes states, $t$ indexes years, and $f$ indexes the size of the household. 
Outcome variables ( $\mathrm{y}$ istf): We test two sets of outcome variables: benefit participation and observed levels of household benefit receipt of TANF, SSI, and SNAP. We define a household as 'participating' in a benefit if any member of the household receives a positive cash value of the benefit in the year of examination. We measure observed levels of household benefit receipt in average monthly values (the annual reported value for a household divided by 12) and in real terms with inflation adjustments derived from the annual CPI-U. We top code levels of household benefit receipt at the $99^{\text {th }}$ percentile (among households receiving the respective benefit).

Figure 2 displays trends in real average monthly benefit levels for SNAP, SSI, and TANF among all single-mother households in our sample (not limited to just those who receive the benefits). Upon the implementation of TANF in 1997, the average single-mother household received approximately $\$ 71$ per month (in 2014 USD) in TANF cash support — similar to the level of SNAP benefits and much higher than the level of SSI benefits. By 2015, however, the average monthly value of TANF had declined to $\$ 22$ per month, while the average level of benefit receipt of SNAP and SSI had increased to $\$ 151$ and $\$ 69$, respectively.

\section{[INSERT FIGURE 2 ABOUT HERE]}

Explanatory variable $\left(\right.$ TANFGen $_{\text {stf }}$ ): Our primary explanatory variable is the generosity of a state's TANF benefits for a given family size. We define 'generosity' as a combination of the level of TANF cash benefits a given household can receive and the income eligibility criteria used to define who can gain access to TANF benefits in a given state and year. We construct a 'simulated' TANF variable to reflect policy-induced changes in the generosity of TANF within states over time. In Appendix A, we provide a step-by-step description of the construction of our simulated TANF generosity variable. Here, we emphasize the two primary features of the 
generosity variable, and how we calculate 'generosity' for each state-year from 1997 to 2015 in accordance with those two features.

First, our TANF generosity variable only captures differences in states' TANF policies and not differences in individual characteristics or demographic features that vary across state or year. An alternative approach that uses differences in state-year means of observed TANF benefit receipt to predict differences in SSI and SNAP receipt would be susceptible to a number of confounding factors in the relationship between TANF generosity and the outcome variables. Our approach is largely able to avoid these concerns. We achieve this by using an identical sample of single mothers (the national sample of single mothers in 1997, the first year of our analysis) for the calculation of generosity in each state-year. This ensures that demographic differences across state or year do not affect the value of the TANF generosity variable.

Second, our conceptualization of TANF generosity takes into account the level of TANF cash benefits to which an eligible household would be entitled and the income eligibility criteria used to define who can gain access to TANF benefits in a given state and year. Given that benefit levels and income-eligibility thresholds are both determined at the state level and fluctuate across state and year, both should be taken into account when assessing the relative generosity of TANF cash assistance. Simply applying the maximum TANF benefit level for a family of three in a given state-year, for example, provides an incomplete assessment of generosity: while it meets the first condition of measuring policy and not demographic differences across state or time, it does not take into account which income levels are actually eligible in a given state and year. To calculate generosity while meeting these criteria, we use TANF policy parameters from the Urban Institute's Welfare Rules Database. We first identify which single mothers in the sample are eligible for TANF cash assistance based on the income eligibility rules (including earned income disregards applied for the purpose of determining eligibility) in each state and year. Among all eligible households, we then calculate the TANF 
benefit value that each would receive based on policy rules in the specific state and year. In doing so, we take into account the number of children in the household $(1,2,3$, or $4+)$ when assessing income eligibility and benefits levels. This calculation is explained in more detail in Appendix A.

After measuring the level of TANF benefits for which each household is eligible, we compute the average TANF benefit value for each 'year-state-household size' cluster (19 years * 51 states $* 4$ household sizes $=3,876$ clusters) in real USD. For example, our sample of single mothers with two children in the state of Washington in 1997 could receive an average TANF benefit of $\$ 137$ per household; for the same family type living in Washington in 2015, however, the average TANF benefit is $\$ 78$ (both values in 2014 USD). This difference in 'generosity' is only due to policy changes made within the state of Washington between 1997 and 2015, and not due to demographic characteristics of the state that have changed over time. The average benefit value for each cluster is operationalized as the simulated TANF generosity variable (TANFGen $\left._{s t f}\right)$ in Equation (1). All childless households headed by a single woman - our comparison group - are allocated a value of zero for the simulated TANF generosity. The evolution of the simulated TANF generosity for each state and household size from 1997 to 2015 is presented in Appendix A.

Demographic \& State Control Variables: $X_{i}$ in Equation (1) represents a vector of individual and household controls. These include the education level of the household head (dummy variable for less than high school degree, with high school degree as the reference group), age of the head (dummy variables for under 25, between 25 and 34, with between 35 to 44 as the reference group), race/ethnicity of the head (black, Hispanic, other race, or Asian, with white as the reference group), and a dummy variable indicating whether the household is located in a rural geographic area. 
State-year controls $\left(\alpha_{\text {st }}\right)$ include a state's real GDP per capita, union density, unemployment rate, and real value of the state's statutory minimum wage (with the federallymandated minimum wage serving as the minimum value for each state-year). We also control for the maximum value of SNAP benefits for the respective family size. As federal changes to maximum SSI benefits are perfectly collinear with our year dummy, we do not include these into our analysis. ${ }^{9}$ To account for the fact that access to TANF benefits is unequal across time and state, we also include a set of three variables to indicate the strictness of TANF sanctions or time limits: dummies to indicate whether the state-year features immediate full-family sanctions, TANF time limits less than 60 months, and TANF family caps (University of Kentucky Center for Poverty Research, 2016; Soss et al., 2008). Similarly, we follow Klerman and Danielson (2011) and include eight indicators of SNAP accessibility to account for differential access to SNAP within states over time (a full list of these indicators can be found in the presentation of summary statistics in Appendix D.) State $\left(\delta_{\mathrm{s}}\right)$, year $\left(\gamma_{\mathrm{t}}\right)$, and household size $\left(\lambda_{\mathrm{f}}\right)$ fixed effects control for, respectively, time invariant differences on the outcome variable that vary across state, national trends or policies that apply across all states but vary by year, and household size effects that may influence the outcome variables. We apply robust standard errors clustered at the state level.

In the modified DD model presented in Equation (1), the simulated TANF generosity provides an estimate of how policy-induced changes in the generosity of TANF benefits affect TANF, SNAP, and SSI participation and household benefit levels. While this is sufficient to evaluate how changes in TANF generosity affect SNAP and SSI benefit allocations, it does not provide an estimate of how changes in observed allocations of TANF cash benefits relate to

\footnotetext{
${ }^{9}$ Some states do offer a supplement to the federal SSI benefit; however, data on the level of these benefits is only available through 2011 . We therefore exclude state supplements to SSI from our primary analysis. In a sensitivity check available upon request, we re-estimate our models over the years 1997 to 2011 while including the state SSI supplements. The indicators have no significant effect on our results.
} 
observed allocations of SSI and SNAP benefits. Consider that a $\$ 50$ per month policy-induced decrease in TANF generosity does not necessarily lead to a $\$ 50$ per month decrease in the TANF benefit allocations (the effect on actual benefit allocations may be smaller or larger than $\$ 50$ per month).

To account for this possibility and to further contextualize our findings, we apply a twostage least-squares (2SLS) estimation to evaluate the relationship between policy-induced changes in TANF benefit allocations (the sum of TANF cash assistance benefits allocated to single-mother households in our sample) versus federal allocations of SSI and SNAP benefits. This follows similar 2SLS (or indirect least squares) estimations applied in Hoynes and Patel (2015) and Schmidt et al. (2016). The first stage estimates the effect of TANF generosity on observed levels of TANF benefit receipt, as follows:

$$
\text { TANF }_{\text {istf }}=\beta_{0}+\beta_{1} \text { TANFGen }_{s t f}+\beta_{2} X_{i}+\beta_{3} \alpha_{s t}+\delta_{s}+\gamma_{t}+\lambda_{f}+\epsilon_{i}
$$

The slope of $\beta_{1}$ provides us the relationship between policy-induced differences in TANF generosity $\left(\right.$ TANFGen $\left._{s t f}\right)$ and the observed allocation of TANF benefits among our sample of single female households ( $T A N F_{i s t f}$, a continuous variable). This is identical to the version of Equation (1) in which observed levels of TANF benefit receipt are set as the outcome variable. We can then apply the predicted value of observed TANF benefit receipt $\left(T A N F_{\text {istf }}\right)$ in our second-stage equation. This is specified as:

$$
y_{i s t f}=\beta_{0}+\beta_{1} T \widehat{A N F}_{\text {istf }}+\beta_{2} X_{i}+\beta_{3} \alpha_{s t}+\delta_{s}+\gamma_{t}+\lambda_{f}+\epsilon_{i}
$$

Equation (3) thus estimates the effect of policy-driven decreases in TANF cash allocations among single-parent households $\left(T \widehat{A N F}_{l s t f}\right)$ on observed allocations of SNAP and 
SSI benefits ( $y_{i s t f}$, a continuous variable indicating level of SNAP or SSI benefits received in the household). For example, we can estimate the monthly increase in SNAP benefit allocations due to TANF policy changes that reduce the average allocation of TANF benefits by $\$ 50$ per month among our sample of single-mother households.

In this case, our 2SLS setup is identical to an indirect least squares estimate. Applying the indirect least squares estimate, we would estimate Equation (2) as a first stage estimate. For the second stage, we would re-estimate Equation (2) but with observed level of SNAP and SSI benefit receipt as the outcome variable. We could then simply divide $\beta_{1}$ from our second stage (the effect of TANF generosity on SNAP/SSI allocations) by $\beta_{1}$ in our first stage (the effect of TANF generosity on TANF allocations) and multiply by 50 to estimate the effect of a $\$ 50$ policy-induced decline in TANF benefit allocations on SNAP and SSI benefit allocations.

\section{Accounting for Measurement Error in the CPS ASEC}

In our primary analysis, we apply the Urban Institute's TRIM3 corrections to account for the substantial underreporting of means-tested transfers (including TANF, SNAP, and SSI) in the CPS ASEC. Whereas the uncorrected CPS ASEC misses about half of TANF and SNAP cash transfers in recent years, the TRIM3-adjusted data comes much closer to capturing the full amount of cash assistance identified in administrative data (Zedlewski and Giannarelli, 2015; Parolin, 2019). TRIM3 matches administrative records on TANF, SNAP, and SSI caseloads across states to impute benefits back into the survey data, allowing for more accurate estimates of SNAP, SSI, and TANF participation and benefit levels.

To do so, TRIM3 first determines the eligibility of each unit or household within the CPS ASEC data for SNAP, TANF, or SSI benefits. As Wheaton and Tran (2018: 30) summarize, TRIM3 “follows the same steps as would be followed by a caseworker, such as applying rules for noncitizens' and students' eligibility, applying the liquid assets (resource) test, computing gross income, calculating deductions to determine net income, and performing 
the income tests." Afterward, monthly benefit values are assigned to each eligible household based on program rules in the given state-year, as well as the size, characteristics, and income of the household. Finally, TRIM3 predicts benefit participation among eligible households. If an individual is eligible for a given program and reports receiving benefits from that program, then TRIM3 keeps the person in its participation count. Among those who are eligible but do not report benefit receipt, TRIM3 simulates participation to meet administrative targets on household type (single-parent household, two-parent household, number of individuals aged $60+$ ), benefit receipt of TANF and SSI, benefit levels (increments of $\$ 1-\$ 50, \$ 51-100$, and so on), state of residence, and citizenship status (Parolin, 2019).

While available evidence suggests that the utilization of these benefit imputations provides an improvement over the unadjusted CPS ASEC, the use of TRIM3-adjusted data does introduce the possibility of measurement error. If the imputed benefits bias the overlap of household participation in SNAP, TANF, and SSI, for example, our results may be over- or under-stated. To account for this possibility, we also estimate our analyses on the unadjusted CPS ASEC data as a sensitivity check. The findings, discussed in more detail later, are not substantively different from our primary analysis.

Still, the unadjusted CPS ASEC also suffers from measurement error - hence the need for the TRIM3 benefit imputations. As a separate sensitivity check on a sample other than the CPS ASEC, we also estimate our results on the SNAP Quality Control (QC) microdata from 1997 to 2015 (the same years as our primary analysis). The QC reports sample households receiving SNAP benefits; thus, we cannot use it to test the effect of TANF generosity on the likelihood of participating in the SNAP program. We can, however, use the QC reports to measure how changes to TANF generosity affect observed levels of SNAP benefit receipt. We discuss this in more detail in the 'Sensitivity Checks' part of the next section. 


\section{Findings}

\section{Descriptive Findings}

We first present descriptive findings with respect to the relationship of the simulated TANF generosity variable and observed TANF, SSI, and SNAP benefit values among singleparent families at the state-year level. In Figure 3, the average simulated TANF generosity for each state-year is plotted on the Y-axis. On the X-axis is, as labeled accordingly, the observed state-year mean of levels of household benefit receipt for the three programs.

\section{[INSERT FIGURE 3 ABOUT HERE]}

As expected, a strong positive correlation $(r=0.79)$ exists between the simulated TANF generosity and the average observed level of household TANF benefits in a state-year. In other words, in state-years where the generosity of TANF benefits is higher (through higher benefit levels and/or higher income cutoffs applied to TANF eligibility), we generally see higher levels of TANF benefits among single-parent households. A negative relationship ( $r=-0.32)$, however, appears to exist between TANF generosity and average observed SNAP benefits, as well as TANF generosity and mean observed SSI benefits in a state-year $(r=-0.09)$. In other words, a higher generosity of TANF benefits is associated with lower observed household benefit levels of SNAP and SSI. Though these findings provide initial support for our primary hypothesis, they are, of course, merely descriptive patterns. We now turn to our regression models to formally evaluate the relationships among the three programs.

\section{Estimation Results}

We begin by presenting our logistic regression estimates of the effect of a state's TANF generosity on the likelihood of participation in the three programs. Table 1 describes these 
findings. The first column shows that greater TANF generosity does relate to higher levels of TANF participation. Specifically, we can estimate that a $\$ 50$ per month (just less than one standard deviation) policy-induced decrease in the generosity of TANF benefits reduces the log odds of participation by around 9.9 percent among single-mother households.

\section{[INSERT TABLE 1 ABOUT HERE]}

The second column displays the estimates for the likelihood of SSI participation. Here, we find a negative and statistically significant relationship between the generosity of TANF benefits and the utilization of SSI among households headed by a single woman. For a $\$ 50$ per month policy-induced decrease in the generosity of TANF benefits, the log odds of receiving SSI benefits increase by around 8.5 percent - closely resembling the effect size of TANF's decline shown in the first column.

The third column shows that the simulated TANF generosity is not significantly related to SNAP participation among single-mother households. This finding aligns with our expectations: on one hand, lower TANF generosity leads to lower TANF participation, and TANF participation grants eligibility for SNAP; on the other hand, lower TANF generosity increases the relative incentive for a household to pursue SNAP benefits directly. The opposing forces effectively 'cancel out' and the estimated effect on participation is close to zero. This may be not the case for household benefit values, however; this is the focus of the next set of analyses. Table 2 presents the results.

[INSERT TABLE 2 ABOUT HERE] 
The first column demonstrates that, as expected, greater TANF generosity leads to higher observed TANF benefit levels. Specifically, a $\$ 50$ per month decrease in TANF generosity is associated with a $\$ 53$ per month decrease in observed levels of TANF benefit receipt for the average household headed by a single mother.

The second and third columns present what are perhaps the more consequential results. We find that TANF generosity is negatively associated with observed levels of both SSI and SNAP benefit receipt. In other words, a policy-induced decrease in TANF generosity is associated with an increase in observed levels of SSI and SNAP benefits among single-mother households. Specifically, we can estimate that a \$50 decrease in TANF generosity would increase SSI benefits by an average $\$ 6$ per month, while SNAP benefits would increase by an average of $\$ 20$ per month. In sum, the $\$ 50$ policy-induced decrease in TANF generosity results in a $\$ 53$ decrease in observed receipt of TANF benefits for the average single-mother household, but a \$26 increase in combined SNAP and SSI benefits.

We can take these estimates a step farther to estimate how a $\$ 50$ policy-induced decline in observed benefit allocations of TANF assistance relate to SSI and SNAP benefit allocations. As described in equations (2) and (3) in the prior section, we perform a two-stage least-squares estimation to predict how a $\$ 50$ policy-induced decrease in allocated TANF benefits relate to increases in allocated SNAP and SSI benefits. Table 3 shows the results.

\section{[INSERT TABLE 3 ABOUT HERE]}

Here, we interpret the coefficients as the effect of policy-induced differences in TANF cash assistance allocations on differences in SSI and SNAP allocations among our population of households headed by a single mother (ages 18 to 44). The final column of Table 3 , for example, suggests that a $\$ 50$ policy-induced decline in TANF benefit allocations contributes to 
a \$25 per month increase in combined SNAP and SSI benefit allocations. ${ }^{10}$ Taking standard errors into account, we can estimate a 95 percent confidence band of a $\$ 17$ to $\$ 32$ increase in SNAP and SSI benefit allocations. Figure 4 contextualizes the key findings by program type.

\section{[INSERT FIGURE 4 ABOUT HERE]}

We estimate that about $\$ 19$ of the gains in federal benefit allocations (76 percent of the total increase) are due to increases in SNAP benefits, and about $\$ 6$ per month (24 percent of the increase) from gains in SSI benefits. In all, the federal government appears to fill in for around half of states' retrenchment of TANF cash assistance generosity.

For further contextualization of the findings, we can also estimate a counterfactual change in TANF and SNAP/SSI benefit allocations in 2015 if each state were to have the same TANF generosity it offered in 1997. For example, how would TANF and SNAP/SSI allocations differ if the state of Washington had not cut its generosity by 40 percent (in real terms) between 1997 and 2015? Moreover, if each state had decided not to alter its TANF generosity, how much more would they collectively allocate in cash assistance? We estimate that state governments would have allocated a collective $\$ 2.2$ billion (2014 USD) more TANF cash assistance to single mothers without a college degree (ages 18-44) in 2015 if each state's generosity were the same as it was in 1997. As a result of this increase in TANF allocations, we estimate that combined federal allocations of SNAP and SSI for single-mother households would have decreased by $\$ 1.3$ billion in 2015 . The net gain for low-income single-mother households would thus be about $\$ 1$ billion more in additional social assistance allocations in 2015 , and in a form - cash

\footnotetext{
${ }^{10}$ Consistent with our explanation of the indirect least squares approach in the prior section, the effect of a policy-induced change in TANF benefit allocations on SNAP/SSI allocations can also be derived by hand from the estimated effects presented in Table 2. Adding the coefficients for SSI and SNAP $(-0.128$ and $-0.391=-$ 0.519 ) and dividing by the coefficient for TANF (1.07) leads to an estimated slope of -0.485 . This is precisely the effect found in the third column of Table 3 using the 2SLS approach.
} 
assistance - that can be spent on a broader bundle of necessities relative to food stamps and is more accessible relative to disability assistance.

\section{Sensitivity Checks}

We perform three sensitivity checks to investigate how our primary findings hold across alternative samples. These include (1) using the unadjusted CPS ASEC data rather than the TRIM3-adjusted version applied in the primary analysis, (2) using SNAP Quality Control microdata to corroborate the relationship between TANF generosity and observed levels of SNAP benefit receipt, and (3) re-estimating our results while applying Tobit models to account for the heavy censorship of our dependent variables.

Uncorrected CPS ASEC Data - Our primary analysis uses the TRIM3-adjusted version of the CPS ASEC that adjusts for the underreporting of TANF, SNAP, and SSI benefits. To account for this possibility of measurement error within the imputations, we re-run our analyses on the unadjusted (standard) CPS ASEC data. The results, as presented in Appendix B, show that the findings closely resemble those of our primary analysis: rather than a $\$ 50$ decline in TANF generosity leading to a $\$ 25$ increase in federal allocations of SNAP and SSI benefits, the analyses using the unadjusted CPS ASEC estimate a \$22 increase in federal benefit allocations. The differences between the two estimates are not statistically significant. Applying the TRIM3-adjusted CPS ASEC thus does not substantially alter the empirical estimates of program interaction. It does, however, provide a more accurate estimate of the relative effect of a policyinduced changes in TANF, as the total allocation of TANF, SNAP, and SSI benefits in the TRIM3-adjusted CPS ASEC much more closely matches administrative data.

SNAP Quality Control Data - We also test whether our results hold when estimated in a separate sample altogether. Specifically, we use microdata from the SNAP Quality Control 
(QC) reports from 1997 to 2015, provided by the U.S. Department of Agriculture (Gray et al., 2015). The QC reports provide annual data on monthly samples of SNAP participants across the U.S. As surveys, the SNAP QC reports are also prone to measurement error; however, they are unique in that they target only households receiving SNAP benefits and, thus, provide a useful and representative portrait of the characteristics of SNAP recipients. We setup the QC sample in the same way as our CPS ASEC samples, identifying households headed by a single female and including the same set of demographic and state-level controls $(n=250,050)$. Just as in our primary sample, we import the TANF generosity indicators based on the state, year, and household size of the single female. Given that all households in the sample received SNAP benefits, we can only estimate the effect of TANF generosity on the intensive margin of SNAP benefit receipt. In other words, the outcome variable is set as the level of SNAP benefits that the given household received during the month.

As shown in Appendix C, we again find a negative and statistically significant effect of TANF generosity on observed SNAP benefit levels. However, the magnitude appears to be smaller than our findings in the CPS ASEC. The results from the QC data suggest that a $\$ 50$ policy-induced decrease in TANF benefit allocations is associated with a $\$ 12$ increase in SNAP benefit allocations (compared to a $\$ 19$ increase in SNAP benefit allocations in our primary analysis). The lower magnitude in the SNAP QC sample appears to be primarily due to all households in the sample receiving at least some level of SNAP benefits. When restricting our CPS ASEC estimates to single-female households receiving at least $\$ 1$ in monthly SNAP benefits, for example, the effect of TANF generosity similarly declines (\$15 increase in SNAP allocations) and is not statistically different from the effect found in the SNAP QC estimates.

Tobit Estimates - As a final sensitivity check, we re-estimate our results using a series of Tobit models rather than an OLS specification. Tobit models, also referred to as censored regression models, are useful in linear estimates when the dependent variable of interest is 
censored at a lower- or upper-bound. In our case, observed levels of SNAP, TANF, and SSI benefit receipt are heavily censored at zero, as much of the population under examination does not receive the respective benefit (this is especially true for TANF and SSI).

Our re-estimates of Equation (1), available upon request, remain statistically significant when estimating the effect of TANF generosity on observed levels of SNAP, TANF, and SSI benefit receipt using the Tobit specification. However, the $\mathrm{T}$ scores for the effect of TANF generosity decrease substantially when switching from OLS to the Tobit model. In our model predicting levels of observed SNAP benefit receipt, TANF generosity is significant only at the 95 percent confidence level. For observed levels of TANF and SSI receipt, the effect of TANF generosity remains significant at the 99 percent confidence level despite the more conservative standard errors. Re-estimating our final 2SLS model as a Tobit with continuous endogenous covariates also produces comparable results to our primary findings: the effect of a change in TANF benefit allocations on change in combined SNAP and SSI allocations increases in magnitude (compared to our OLS estimate in the primary analysis) while the $\mathrm{Z}$ score remains roughly the same.

We do not directly interpret the magnitude of the results (the coefficients) from the Tobit models in the same way as our OLS estimates. In technical terms, the Tobit coefficient measures the probability of receiving a positive value of the respective benefit multiplied by the value of the benefit among those who receive it (McDonald and Moffitt, 1980). Thus, we focus our sensitivity check on the continuity of the direction and statistical significance of the effects. As such, the results of the Tobit models appear to support our primary findings.

\section{Discussion}

The divergent trends in benefit allocations of the state-managed TANF program and federally-financed SNAP and SSI programs served as the starting point for this paper. Though 
cash assistance from the TANF has declined throughout the past two decades, participation in SNAP and SSI programs has gradually increased. We set out to understand the relationship between these trends, hypothesizing that retrenchment in the generosity of TANF has contributed to increases in SNAP and SSI benefit allocations.

Our findings corroborate this hypothesis, suggesting that a $\$ 50$ policy-induced decline in states' TANF allocations leads to an increase of between $\$ 17$ to $\$ 32$ per month in federal allocations of SNAP and SSI benefits among single-mother households. In other words, the rise of SNAP benefit allocations throughout the past two decades is not solely due to rising unemployment, increases in benefit levels, or broadening eligibility requirements. Instead, the evidence suggests that declining TANF generosity has contributed to an increase in SNAP benefit levels for the average single-mother household. Similarly, the rise in SSI benefit allocations cannot be attributed solely to economic circumstances or increases in the number of individuals with disabilities. Instead, the evidence suggests that the decline of TANF generosity has increased the relative incentive for eligible individuals to pursue SSI benefits. These findings are consistent with economic theories of program participation: as the relative gains of participating in a social assistance program increase, a greater share of eligible households appear to do so.

We proposed that the relationship between TANF, SNAP, and SSI carries consequences for state governments and low-income households alike. From a household income perspective, we find that despite TANF retrenchment generating increases in SNAP and SSI benefit allocations, the decline of TANF has still led to net losses in the provision of social assistance in the U.S. In a counterfactual scenario in which states had not retrenched their TANF generosity from 1997 onward, for example, we estimated that the net gain in social assistance spending would be about $\$ 1$ billion more in 2015 (in 2014 USD). At the same time, it is important to recognize that the rise of SSI and SNAP benefits have, for the average household, 
partially offset TANF's decline. The federal government compensates around 50 cents for every dollar pulled back from declines in TANF benefit generosity. Thus, rather than straightforward retrenchment in the provision of cash assistance, the decline of TANF has in part led to a shift toward federally-funded social assistance benefits. That said, the net distributive effects of these program interactions are not even across households: among households where no individuals are plausibly eligible for SSI, for example, the average increase in SSI expenditures carries little meaning. Excluding SSI from our calculations, we see that a $\$ 50$ decline in TANF is associated with \$19 increase in SNAP (see Figure 3), rather than the combined \$25 increase when SSI was included.

From the perspective of state governments, the negative relationship between TANF generosity and SNAP/SSI benefit allocations leads to two important findings. First, state governments have an ability to shift the burden of cash assistance to the federal government through a retrenchment of TANF cash support. In other words, cutting back on their own cash assistance support allows states to induce greater federal expenditures on SNAP and SSI. This pattern serves as a case of institutional moral hazard. Moral hazard at the individual level refers to the ability of an insured individual to influence the liability of the insurer (Barr, 2004); similarly, institutional moral hazard, as discussed in Vandenbroucke et al. (2016), reflects the ability of state governments to influence the extent to which the federal government is liable for protecting against the societal risks of poverty and deprivation.

This institutional moral hazard partially contradicts one important aim of welfare reform: reducing the ability of state governments to unilaterally induce federal expenditures. As described before, the federal government would match at least 50 percent of states' allocations of cash assistance prior to the introduction of TANF. The block grant funding structure introduced during the transition to TANF was designed in part to sever the relationship between state's cash assistance caseloads and federal expenditures. Our findings show, 
however, that state governments can still affect federal expenditures through fluctuations in TANF caseloads, even if through a more indirect mechanism than before.

Second, the negative relationship between TANF and SNAP/SSI benefit allocations, combined with the flexibility allowed to states in allocating their TANF block grant, plausibly provides state governments a financial incentive to disinvest in cash assistance. While we do not presume that the program interactions showcased in this paper serve as a motivation for state policymakers to cut back on cash assistance, the findings nonetheless reveal that a disincentive structure exists: spending less on TANF cash assistance has the dual effect of shifting the burden of social assistance to the federal government and preserving TANF funds that can be used to supplant general state revenues (Germanis, 2015; Kubik, 2003).

Evidence from government reports and state documents suggests that these 'preserved' TANF resources are used to fund programs such as foster care services, family health programs, dental assistance, compulsive gambler support, grants to private foundations, and a variety of other programs or services that are only tangentially related to TANF's core purposes (Parolin, 2018; U.S. General Accounting Office, 2001). Indeed, the General Accounting Office (2001) tracked 10 states' TANF funding decisions in 1999-2000 and found that 'supplantation' was a common practice within each. State documents also acknowledge the practice: a state report from Montana, for example, explicitly describes its "innovative and creative uses of TANF and state MOE funds" to "reduce general fund expenditures" (Gervais, 2000: 1). The document provides a list of state services that could be shifted under the funding structure of TANF in order to preserve more than $\$ 3.2$ million per year of its general state revenues. Consider also that by 2014, 10 states allocated less than 10 percent of their TANF budgets toward the provision of cash assistance.

Finally, several possibilities exist for future research to build on our findings or to address the limitations of our study. First, future research should continue to parse the intention 
and motives of policymakers in determining how to allocate their TANF funds. Though our evaluation of state TANF benefit allocations makes a compelling case that a disincentive structure exists with respect to states' provision of cash assistance, our reliance on quantitative data is nonetheless limiting in its ability to capture the precise motives of state governments. Second, as our conceptualization of TANF generosity focuses primarily on benefit levels and income eligibility standards, we are likely to underestimate the extent to which state policy decisions lead to declines in received TANF benefits and gains in SNAP/SSI benefits. Future analyses might go further to understand how state outreach efforts and differences in conditionality or sanctioning schemes exacerbate the threat of institutional moral hazard. Moreover, future analyses of program interaction in the U.S. might expand beyond the TANF program and seek to understand how differences in states' minimum wage policies, for example, relate to increased federal spending on SNAP, SSI or the Earned Income Tax Credit. More generally, future research should continue to measure and understand the relationship between state- and federally-funded social transfer programs in the U.S. As this study shows, focusing solely on changes in benefit allocations in one program, such as TANF, may mask interaction effects that partially mitigate the social consequences of the program's decline. How low-income households and state governments respond to the incentive structures that these program interactions create deserves continued attention as American welfare state research moves forward. 


\section{References}

Barr NA. (2004) The economics of the welfare state, Oxford: Oxford University Press.

Beatty TKM and Tuttle CJ. (2015) Expenditure Response to Increases in In-Kind Transfers: Evidence from the Supplemental Nutrition Assistance Program. American Journal of Agricultural Economics 97: 390-404.

Blank RM. (2002) Evaluating Welfare Reform in the United States. National Bureau of Economic Research Working Paper Series No. 8983.

Bound J, Kossoudji SA and Ricart-Moes G. (1998) The Ending of General Assistance and SSI Disability Growth in Michigan. In: Rupp K and Stapleton DC (eds) In Growth in Disability Benefits: Explanations and Policy Implications. Kalamazoo, MI: W.E. Upjohn Institute for Employment Research.

Center on Budget \& Policy Priorities. (2017) A Quick Guide to SNAP Eligibility and Benefits. Available at: https://www.cbpp.org/research/a-quick-guide-to-snap-eligibility-andbenefits.

Chernick H. (2000) Federal Grants and Social Welfare Spending: Do State Responses Matter? National Tax Journal 53: 143-152.

Cutler DM and Gruber J. (1996) Does Public Insurance Crowd out Private Insurance? The Quarterly Journal of Economics 111: 391-430.

Danziger S, Chavez K and Cumberworth E. (2012) Poverty and the Great Recession. Recession Trends: The Russell Sage Foundation and The Stanford Center on Poverty and Inequality.

Edin K and Shaefer HL. (2016) \$2.00 A Day: Living on Almost Nothing in America, Boston: Mariner Books.

Eissa N and Hoynes H. (2004) Taxes and the labor market participation of married couples: the earned income tax credit. Journal of Public Economics 88: 1931-1958.

Falk G. (2014) Temporary Assistance for Needy Families (TANF): Eligibility and Benefit Amounts in State TANF Cash Assistance Programs Congressional Research Service.

Falk G. (2016) The Temporary Assistance for Needy Families (TANF) Block Grant: Responses to Frequently Asked Questions. Congressional Research Service.

Falk G and Aussenberg RA. (2014) The supplemental nutrition assistance program (SNAP): Categorical eligibility. Congressional Research Service.

Farrell M. (2013) Connections between TANF and SSI: Lessons from the TANF/SSI disability transition project. Office of Planning, Research and Evaluation, Administration for Children and Families, U.S. Department of Health and Human Services No. 2013-57.

Ganong P and Liebman JB. (2018) The Decline, Rebound, and Further Rise in SNAP Enrollment: Disentangling Business Cycle Fluctuations and Policy Changes. American Economic Journal: Economic Policy 10: 153-176.

Garrett B and Glied S. (2000) Does State AFDC Generosity Affect Child SSI Participation? Journal of Policy Analysis and Management 19: 275-295.

Germanis P. (2015) TANF is Broken! It's Time to Reform "Welfare Reform". 
Gervais P. (2000) Flexible Spending of TANF and State MOE Funds. Legislative Finance Committee of Montana.

Gray KF, Fisher S and Lauffer S. (2015) Characteristics of Supplemental Nutrition Assistance Program Households: Fiscal Year 2015. U.S. Department of Agriculture.

Grogger J, Karoly L and Klerman JA. (2002) Consequences of Welfare Reform: A Research Synthesis. RAND Corporation.

Hoke C. (1998) State Discretion Under New Federal Welfare Legislation: Illusion, Reality, and a FederalismBased Constitutional Challenge. Standard Law \& Policy Review 115.

Hoynes HW and Luttmer EFP. (2010) The Insurance Value of State Tax-and-Transfer Programs. National Bureau of Economic Research Working Paper Series No. 16280.

Hoynes HW and Patel AJ. (2015) Effective Policy for Reducing Inequality? The Earned Income Tax Credit and the Distribution of Income. National Bureau of Economic Research Working Paper Series No. 21340.

Hoynes HW and Schanzenbach DW. (2009) Consumption Responses to In-Kind Transfers: Evidence from the Introduction of the Food Stamp Program. American Economic Journal: Applied Economics 1: 109-139.

Institute TU. (2015) Welfare Rules Databook and Database.

Jones LE and Michelmore K. (2016) The Impact of the Earned Income Tax Credit on Household Finances. Social Science Research Network.

Keane M and Moffitt R. (1998) A Structural Model of Multiple Welfare Program Participation and Labor Supply. International Economic Review 39: 553-589.

Klerman JA and Danielson C. (2011) The transformation of the Supplemental Nutrition Assistance Program. Journal of Policy Analysis and Management 30: 863-888.

Kubik J. (2003) Fiscal Federalism and Welfare Policy: The Role of States in the Growth of Child SSI. National Tax Journal 56: 61-79.

LIS. (2016) Disposable Household Income.

Loprest P and Maag E. (2009) Disabilities among TANF recipients: Evidence from the NHIS - final report. The Urban Institute.

McDonald JF and Moffitt R. (1980) The Uses of Tobit Analysis. The Review of Economic Studies 62: 318-321.

Milligan K and Stabile M. (2011) Do Child Tax Benefits Affect the Well-Being of Children? Evidence from Canadian Child Benefit Expansions. American Economic Journal: Economic Policy 3: 175-205.

Moffitt R. (2015) Multiple Program Participation and the SNAP Program, Stanford, CA: Stanford University Press.

Parolin Z. (2018) Race, Social Assistance, and the Risk of Child Poverty Across the 50 United States. CSB Working Paper Series 18/04.

Parolin Z. (2019) The Effect of Benefit Underreporting on Estimates of Poverty in the United States. Social Indicators Research.

Schmidt L. (2004) Effects of Welfare Reform on the Supplemental Security Income (SSI) Program. National Poverty Center Policy Brief 4. 
Schmidt L. (2012) The Supplemental Security Income Program and Welfare Reform. Federal Reserve Bank of Boston: Public Policy Discussion Papers.

Schmidt L and Sevak P. (2004) AFDC, SSI, and Welfare Reform Aggressiveness: Caseload Reductions versus Caseload Shifting. The Journal of Human Resources 39: 792-812.

Schmidt L, Shore-Sheppard L and Watson T. (2016) The Effect of Safety Net Programs on Food Insecurity. The Journal of Human Resources 51: 589-614.

Short K. (2012) The Research Supplemental Poverty Measure: 2011. Current Population Reports.

Skemer M and Bayes B. (2013) Examining the Interaction Between Welfare and Disability: Lessons from an In-Depth Data Analysis. OPRE Report 2013-49: Office of Planning, Research and Evaluation, Administration for Children and Families, U.S. Department of Health and Human Services.

Smeeding TM and Rainwater L. (2001) Poverty Across States, Nations \& Continents. In: Vlemincx K and Smeeding T (eds) Child wellbeing, child poverty, and child policy in modern nations. Policy Press at University of Bristol.

Social Security Administration. (2017) SSI Annual Statisitical Report, 2015. Social Security: Research, Statistics, \& Policy Analysis.

Soss J, Fording RC and Schram SF. (2008) The Color of Devolution: Race, Federalism, and the Politics of Social Control. American Journal of Political Science 52: 536-553.

U.S. General Accounting Office. (2001) Welfare Reform: Challenges in Maintaining a Federal-State Fiscal Partnership. Report to Congressional Requesters No. GAO-01828.

U.S. General Accounting Office. (2012) Supplemental nutrition assistance program improved oversight of state eligibility expansions needed. Report to Congressional Requesters No. GAO-12-670.

University of Kentucky Center for Poverty Research. (2016) UKCPR National Welfare Data, 1980 to 2015. In: Gatton College of Business and Economics UoK, Lexington, KY (ed).

Vandenbroucke F, Luigjes C, Wood D, et al. (2016) Institutional Moral Hazard in the Multitiered Regulation of Unemployment and Social Assistance Benefits and Activation: A summary of eight country case studies. CEPS Special Report No. 137.

Wheaton L and Tran V. (2018) The Antipoverty Effects of the Supplemental Nutrition Assistance Program. The Urban Institute Research Report.

Wiseman M and Wamhoff S. (2006) The TANF/SSI Connection. Social Security Bulletin 66: 21-36.

Zedlewski S and Giannarelli L. (2015) TRIM: A Tool for Social Policy Analysis. The Urban Institute.

Ziliak JP. (2015) Why are so many Americans on food stamps? The role of economy, policy, and demographics, Stanford, CA: Stanford University Press. 


\section{Figures \& Tables}

Figure 1: Share of single mothers (age 18-44) receiving TANF, SNAP, and SSI benefits from $1997-2015$

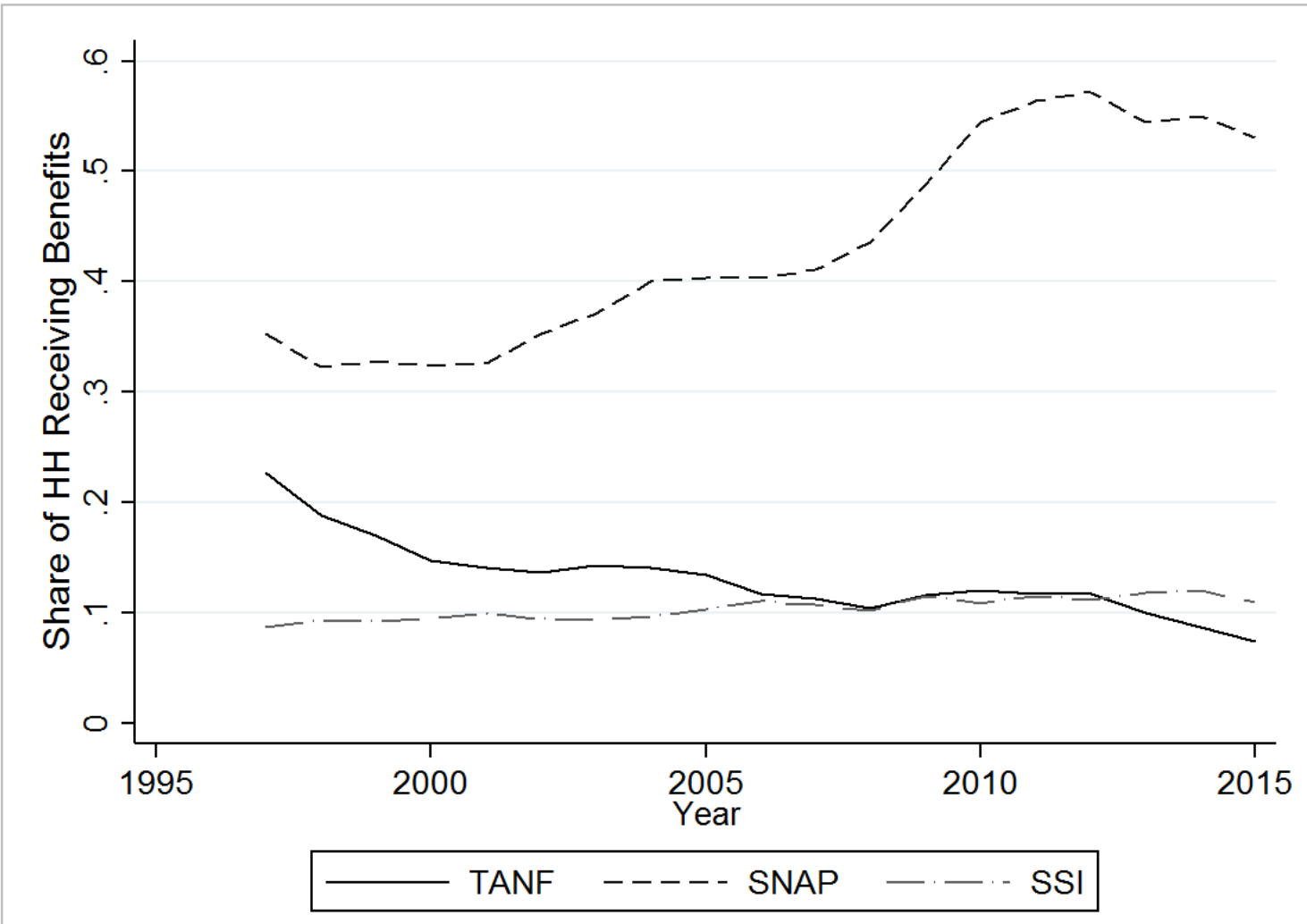

Note: Benefit participation levels are derived from the CPS ASEC applying TRIM3 benefit imputations for TANF, SSI, and SNAP. Participation in a benefit indicates that the household received a positive value of the benefit in the income reference period. Sample includes single mothers between the ages of 18 and 44 without a college degree. Figure is the authors' own. 
Figure 2: Real average annual benefit receipt among single mothers (age 18-44), 1997 - 2015

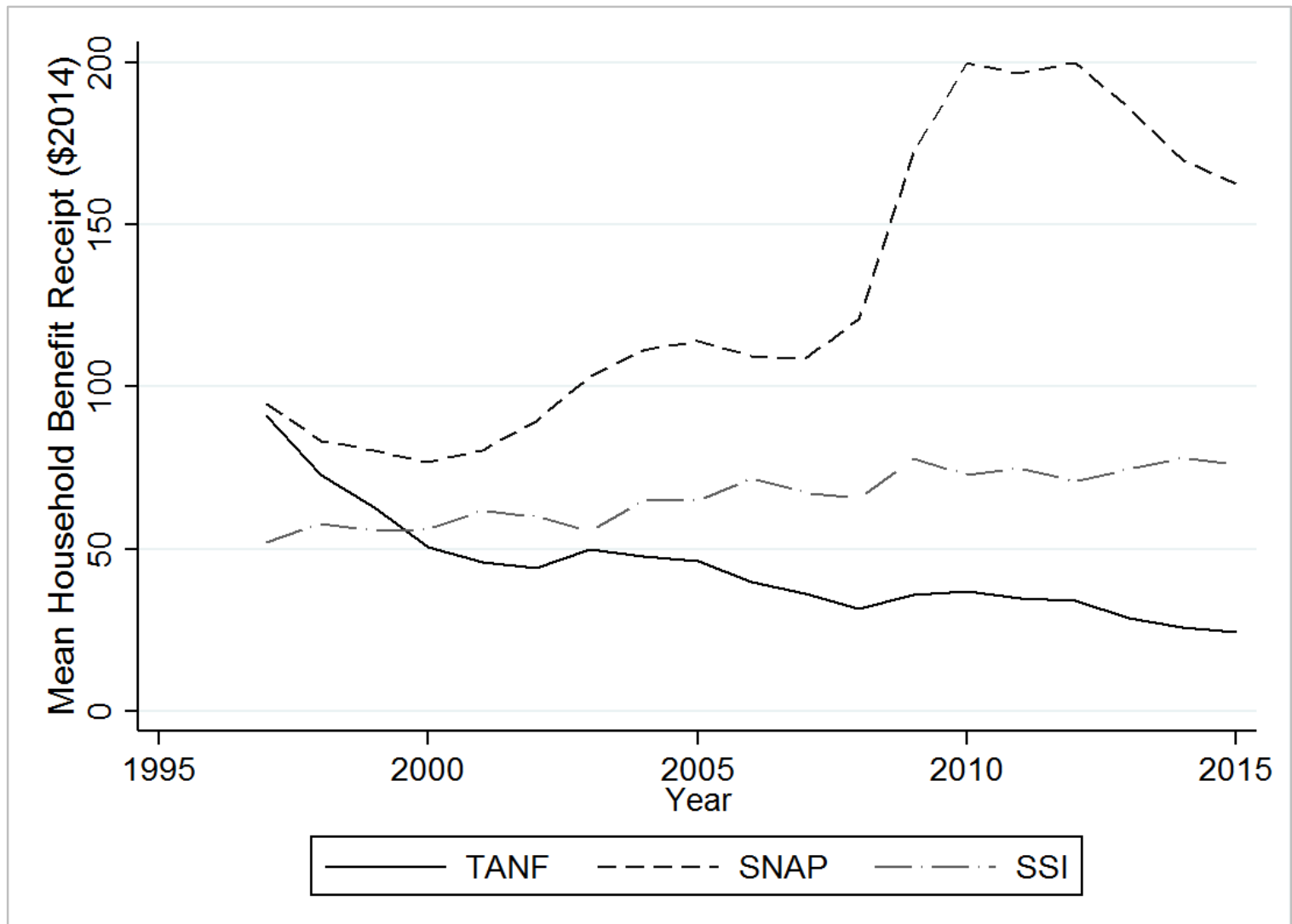

Note: Benefit levels are derived from the CPS ASEC applying TRIM3 benefit imputations for TANF, SSI, and SNAP. Mean household benefit levels include all single mothers (age 18 to 44) without a college degree, including those that received zero value of the benefit during the income reference period. Figure is the authors' own. 
Figure 3: Bivariate relationship between mean TANF generosity in state-year and mean observed TANF, SNAP, and SSI benefit receipt
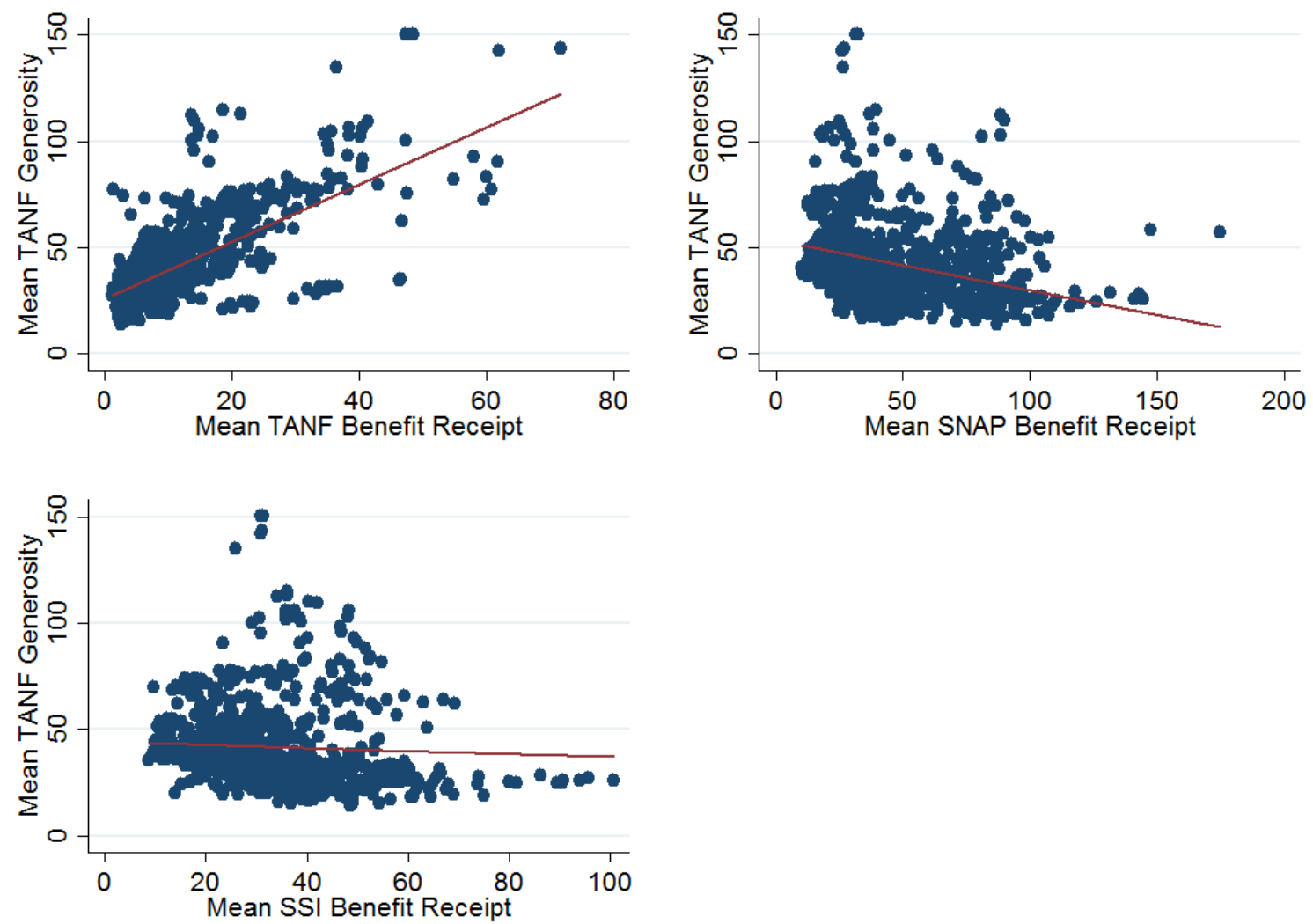

Note: The correlations for TANF, SNAP, and SSI benefit receipt are, respectively, $r=0.79, r=-0.32$,. And r=0.09. Alaska, Hawaii, and Washington, D.C. tend to feature benefit values that deviate from the 48 contiguous United States (for example, these three states represent the apparent outliers in TANF benefit receipt figure). When these three states are removed, the correlations for TANF, SNAP, and SSI benefit receipt are, respectively, $\mathrm{r}=0.84, \mathrm{r}=-0.36$, and $\mathrm{r}=.-0.07$. 
Figure 4: Estimated effect of $\$ 50 /$ mo policy-induced decrease in TANF benefit allocations on average levels of SSI \& SNAP benefit receipt among single mothers (ages 18-44 without college education)

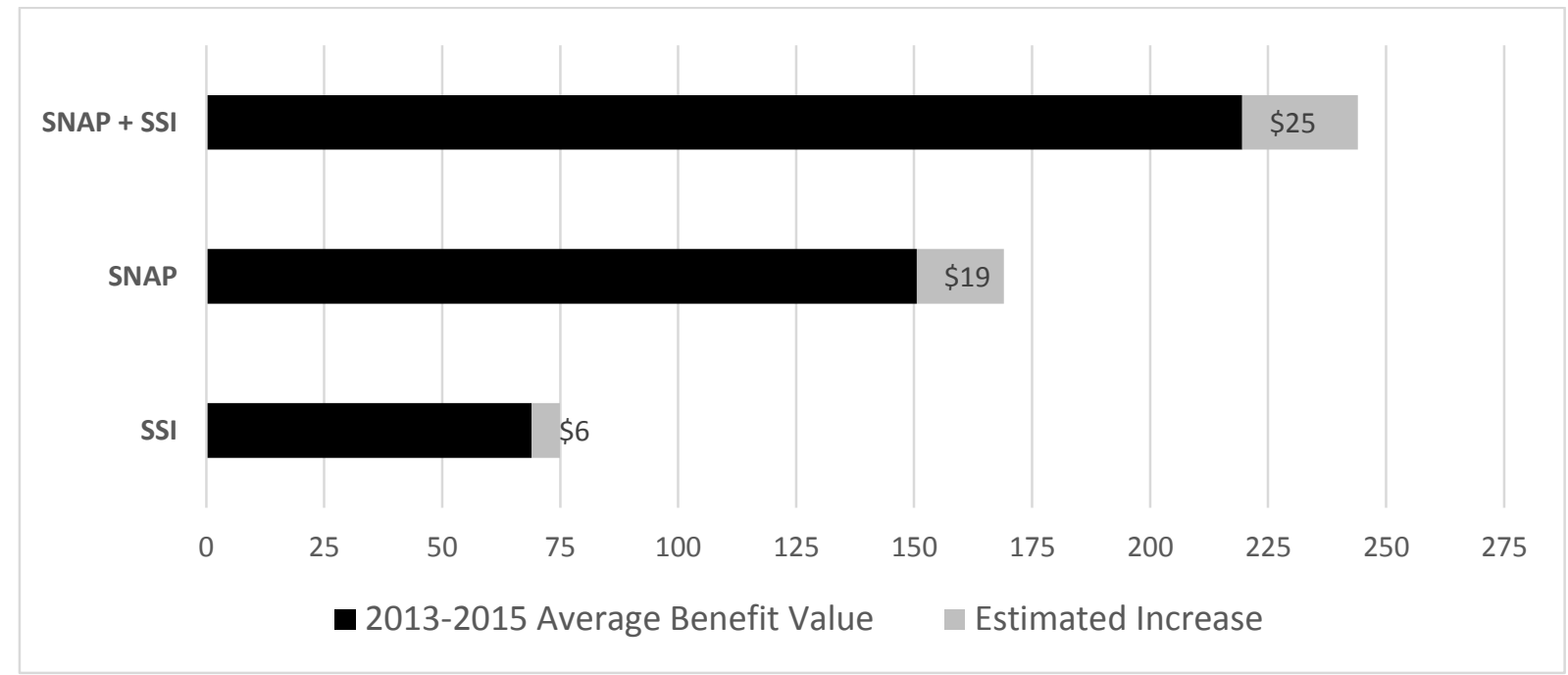

Note: Figure depicts results from Table 3. 
Table 1: Logistic Regression Estimates of Effect of State TANF Generosity on TANF, SSI \& SNAP Participation

\begin{tabular}{|c|c|c|c|}
\hline & $\begin{array}{c}\text { TANF } \\
\text { Participation }\end{array}$ & $\begin{array}{c}\text { SSI } \\
\text { Participation }\end{array}$ & $\begin{array}{c}\text { SNAP } \\
\text { Participation }\end{array}$ \\
\hline Simulated TANF Generosity & $\begin{array}{l}0.002^{* * *} \\
(0.001)\end{array}$ & $\begin{array}{c}-0.002^{* * * *} \\
(0.000)\end{array}$ & $\begin{array}{c}0.001 \\
(0.001)\end{array}$ \\
\hline
\end{tabular}

State Controls

\begin{tabular}{|c|c|c|c|}
\hline State GDP Per Cap. & $\begin{array}{c}1.071 \\
(0.879)\end{array}$ & $\begin{array}{l}-0.496 \\
(0.464)\end{array}$ & $\begin{array}{l}-1.029^{*} \\
(0.481)\end{array}$ \\
\hline State Union Density & $\begin{array}{c}0.006 \\
(0.011)\end{array}$ & $\begin{array}{l}-0.001 \\
(0.016)\end{array}$ & $\begin{array}{l}-0.008 \\
(0.012)\end{array}$ \\
\hline State Unemployment Rate & $\begin{array}{c}0.033 \\
(0.023)\end{array}$ & $\begin{array}{l}-0.015 \\
(0.025)\end{array}$ & $\begin{array}{l}0.039^{*} \\
(0.016)\end{array}$ \\
\hline State Minimum Wage & $\begin{array}{l}-0.034 \\
(0.042)\end{array}$ & $\begin{array}{c}0.038 \\
(0.039)\end{array}$ & $\begin{array}{l}-0.053^{*} \\
(0.021)\end{array}$ \\
\hline $\begin{array}{l}\text { TANF, Immediate Full- } \\
\text { Family Sanction }\end{array}$ & $\begin{array}{l}-0.515^{* * *} \\
(0.120)\end{array}$ & $\begin{array}{l}0.095^{*} \\
(0.048)\end{array}$ & $\begin{array}{c}0.046 \\
(0.057)\end{array}$ \\
\hline Strict TANF Time Limits & $\begin{array}{l}-0.106 \\
(0.187)\end{array}$ & $\begin{array}{l}-0.092 \\
(0.060)\end{array}$ & $\begin{array}{c}0.010 \\
(0.108)\end{array}$ \\
\hline TANF Family Cap & $\begin{array}{c}0.177 \\
(0.203)\end{array}$ & $\begin{array}{l}-0.010 \\
(0.095)\end{array}$ & $\begin{array}{c}-0.092 \\
(0.061)\end{array}$ \\
\hline Max SNAP Benefits & $\begin{array}{l}0.003^{*} \\
(0.001)\end{array}$ & $\begin{array}{c}0.002 \\
(0.001)\end{array}$ & $\begin{array}{l}0.002^{* *} \\
(0.001)\end{array}$ \\
\hline SNAP Asset Test Increase & $\begin{array}{c}0.025 \\
(0.082)\end{array}$ & $\begin{array}{c}0.030 \\
(0.059)\end{array}$ & $\begin{array}{c}0.026 \\
(0.044)\end{array}$ \\
\hline $\begin{array}{l}\text { Combined SNAP \& SSI } \\
\text { Application }\end{array}$ & $\begin{array}{l}-0.041 \\
(0.086)\end{array}$ & $\begin{array}{c}0.023 \\
(0.057)\end{array}$ & $\begin{array}{l}0.100^{*} \\
(0.050)\end{array}$ \\
\hline $\begin{array}{l}\text { Share of SNAP Recipients } \\
\text { with Recertification Periods } \\
\text { under Three Months }\end{array}$ & $\begin{array}{l}-0.173 \\
(0.183)\end{array}$ & $\begin{array}{l}-0.030 \\
(0.085)\end{array}$ & $\begin{array}{l}-0.137 \\
(0.108)\end{array}$ \\
\hline $\begin{array}{l}\text { Share of SNAP Benefits as } \\
\text { EBT Payments }\end{array}$ & $\begin{array}{c}0.163 \\
(0.086)\end{array}$ & $\begin{array}{l}-0.072 \\
(0.064)\end{array}$ & $\begin{array}{c}0.025 \\
(0.070)\end{array}$ \\
\hline $\begin{array}{l}\text { Fingerprinting During } \\
\text { SNAP Eligibility }\end{array}$ & $\begin{array}{l}-0.201 \\
(0.105)\end{array}$ & $\begin{array}{c}0.016 \\
(0.050)\end{array}$ & $\begin{array}{c}-0.248^{* * * *} \\
(0.074)\end{array}$ \\
\hline
\end{tabular}




$\begin{array}{lccc}\begin{array}{l}\text { SNAP Eligibility Extended } \\ \text { to Noncitizens }\end{array} & -0.092 & -0.103^{*} & -0.192^{* * * *} \\ & (0.114) & (0.049) & (0.048) \\ \begin{array}{l}\text { Simplified SNAP Reporting } \\ \text { Procedures }\end{array} & -0.033 & -0.034 & 0.091 \\ & (0.074) & (0.044) & (0.072) \\ \begin{array}{l}\text { Vehicle Exemption in Asset } \\ \text { Test }\end{array} & 0.083 & -0.056 & 0.030 \\ & (0.067) & (0.051) & (0.052)\end{array}$

Demographic Controls

\begin{tabular}{|c|c|c|c|}
\hline Less Than High School & $\begin{array}{c}0.694^{* * *} \\
(0.036)\end{array}$ & $\begin{array}{c}0.674^{* * *} \\
(0.039)\end{array}$ & $\begin{array}{c}0.707^{* * *} \\
(0.021)\end{array}$ \\
\hline Under 25 Years Old & $\begin{array}{c}0.821^{* * *} \\
(0.029)\end{array}$ & $\begin{array}{c}-0.480^{\text {*** }} \\
(0.041)\end{array}$ & $\begin{array}{c}0.561^{* * *} \\
(0.021)\end{array}$ \\
\hline 25 to 34 Years Old & $\begin{array}{c}0.227^{* * *} \\
(0.027)\end{array}$ & $\begin{array}{c}-0.199^{* * *} \\
(0.026)\end{array}$ & $\begin{array}{c}0.209^{* * *} \\
(0.019)\end{array}$ \\
\hline Black & $\begin{array}{c}0.593^{* * *} \\
(0.032)\end{array}$ & $\begin{array}{c}0.339^{* * * *} \\
(0.040)\end{array}$ & $\begin{array}{c}0.527^{* * *} \\
(0.027)\end{array}$ \\
\hline Hispanic & $\begin{array}{l}0.197^{* *} \\
(0.064)\end{array}$ & $\begin{array}{c}0.270^{* * *} \\
(0.047)\end{array}$ & $\begin{array}{c}0.170^{* * * *} \\
(0.050)\end{array}$ \\
\hline Other Race & $\begin{array}{l}0.171^{* *} \\
(0.061)\end{array}$ & $\begin{array}{c}0.362^{* * *} \\
(0.061)\end{array}$ & $\begin{array}{c}0.352^{* * *} \\
(0.049)\end{array}$ \\
\hline Asian & $\begin{array}{c}-0.325^{\text {**** }} \\
(0.065)\end{array}$ & $\begin{array}{c}-0.061 \\
(0.068)\end{array}$ & $\begin{array}{c}-0.541^{* * *} \\
(0.058)\end{array}$ \\
\hline Rural & $\begin{array}{l}0.096^{* *} \\
(0.037)\end{array}$ & $\begin{array}{c}0.220^{* * *} \\
(0.045)\end{array}$ & $\begin{array}{c}0.273^{* * *} \\
(0.035)\end{array}$ \\
\hline State Fixed Effects & $\mathrm{X}$ & $X$ & $\mathrm{X}$ \\
\hline Year Fixed Effects & $\mathrm{X}$ & $X$ & $\mathrm{X}$ \\
\hline Family Size Fixed Effects & $\mathrm{X}$ & $\mathrm{X}$ & $\mathrm{X}$ \\
\hline Dbservations & 117,219 & 117,219 & 117,219 \\
\hline
\end{tabular}

Participation in a benefit indicates that the household received a positive value of the benefit in the reference year. Sample includes households headed by a single female without a college degree between the ages of 18 and 44. Standard errors in parentheses. ${ }^{*} p<0.05,{ }^{* *} p<0.01,{ }^{* * *} p<0.001$. 
Table 2: OLS Estimates Effect of State TANF Generosity on Observed Levels of TANF, SSI \& SNAP Household Benefit Receipt

\begin{tabular}{lccc}
\hline & $\begin{array}{c}\text { Monthly TANF } \\
\text { Benefits }\end{array}$ & $\begin{array}{c}\text { Monthly SSI } \\
\text { Benefits }\end{array}$ & $\begin{array}{c}\text { Monthly } \\
\text { SNAP Benefits }\end{array}$ \\
\hline Simulated TANF & $1.07^{* * * *}$ & $-0.13^{*}$ & $-0.39^{* * * *}$ \\
Generosity & $(0.05)$ & $(0.05)$ & $(0.04)$
\end{tabular}

\section{State Controls}

\begin{tabular}{|c|c|c|c|}
\hline State GDP Per Cap. (log) & $\begin{array}{c}-35.22 \\
(33.29)\end{array}$ & $\begin{array}{l}-31.99 \\
(28.11)\end{array}$ & $\begin{array}{l}-31.56 \\
(30.59)\end{array}$ \\
\hline State Union Density & $\begin{array}{c}0.31 \\
(0.59)\end{array}$ & $\begin{array}{l}-0.32 \\
(0.88)\end{array}$ & $\begin{array}{l}-0.99 \\
(0.63)\end{array}$ \\
\hline $\begin{array}{l}\text { State Unemployment } \\
\text { Rate }\end{array}$ & $\begin{array}{c}0.93 \\
(1.48)\end{array}$ & $\begin{array}{l}-2.68 \\
(1.86)\end{array}$ & $\begin{array}{c}1.89 \\
(1.19)\end{array}$ \\
\hline State Minimum Wage & $\begin{array}{l}-6.29^{* *} \\
(2.03)\end{array}$ & $\begin{array}{l}1.85 \\
(3.16)\end{array}$ & $\begin{array}{l}-4.18^{*} \\
(1.72)\end{array}$ \\
\hline $\begin{array}{l}\text { TANF, Immediate Full- } \\
\text { Family Sanction }\end{array}$ & $\begin{array}{l}-2.97 \\
(3.21)\end{array}$ & $\begin{array}{c}3.59 \\
(3.73)\end{array}$ & $\begin{array}{c}3.74 \\
(3.20)\end{array}$ \\
\hline $\begin{array}{l}\text { Strict TANF Time } \\
\text { Limits }\end{array}$ & $\begin{array}{l}-7.66 \\
(5.00)\end{array}$ & $\begin{array}{l}-4.05 \\
(3.73)\end{array}$ & $\begin{array}{c}7.75 \\
(9.18)\end{array}$ \\
\hline TANF Family Cap & $\begin{array}{l}-1.05 \\
(4.22)\end{array}$ & $\begin{array}{c}3.76 \\
(4.39)\end{array}$ & $\begin{array}{l}-3.20 \\
(4.61)\end{array}$ \\
\hline Max SNAP Benefits & $\begin{array}{l}-0.09 \\
(0.08)\end{array}$ & $\begin{array}{c}0.27^{*} \\
(0.10)\end{array}$ & $\begin{array}{l}1.59^{* * * *} \\
(0.18)\end{array}$ \\
\hline $\begin{array}{l}\text { SNAP Asset Test } \\
\text { Increase }\end{array}$ & $\begin{array}{l}-0.44 \\
(2.46)\end{array}$ & $\begin{array}{l}3.52 \\
(4.78)\end{array}$ & $\begin{array}{l}0.18 \\
(3.12)\end{array}$ \\
\hline $\begin{array}{l}\text { Combined SNAP \& SSI } \\
\text { Application }\end{array}$ & $\begin{array}{l}1.00 \\
(3.85)\end{array}$ & $\begin{array}{c}3.44 \\
(3.50)\end{array}$ & $\begin{array}{c}3.40 \\
(2.93)\end{array}$ \\
\hline $\begin{array}{l}\text { Share of SNAP } \\
\text { Recipients with } \\
\text { Recertification Periods } \\
\text { under Three Months }\end{array}$ & $\begin{array}{l}-12.05 \\
(6.39)\end{array}$ & $\begin{array}{c}1.61 \\
(4.96)\end{array}$ & $\begin{array}{l}-0.51 \\
(5.18)\end{array}$ \\
\hline $\begin{array}{l}\text { Share of SNAP Benefits } \\
\text { as EBT Payments }\end{array}$ & $\begin{array}{c}2.31 \\
(5.86)\end{array}$ & $\begin{array}{l}-0.18 \\
(3.18)\end{array}$ & $\begin{array}{c}1.78 \\
(2.70)\end{array}$ \\
\hline Fingerprinting During & -2.54 & -1.35 & $-16.00^{* * *}$ \\
\hline
\end{tabular}


SNAP Eligibility

(4.61)

SNAP Eligibility

$-15.14^{*}$

(6.82)

$-1.65$

(3.06)

Reporting Procedures

Vehicle Exemption in

Asset Test

3.00

(2.05)

\section{Demographic Controls}

\begin{tabular}{|c|c|c|c|}
\hline Less Than High School & $\begin{array}{c}22.34^{* * * *} \\
(4.79)\end{array}$ & $\begin{array}{c}39.94^{* * * *} \\
(2.53)\end{array}$ & $\begin{array}{c}43.63^{* * * *} \\
(1.38)\end{array}$ \\
\hline Under 25 Years Old & $\begin{array}{c}24.51^{* * *} \\
(4.39)\end{array}$ & $\begin{array}{c}-23.64^{* * *} \\
(1.89)\end{array}$ & $\begin{array}{c}47.10^{* * * *} \\
(1.82)\end{array}$ \\
\hline 25 to 34 Years Old & $\begin{array}{l}9.07^{* * * *} \\
(2.30)\end{array}$ & $\begin{array}{c}-13.31^{* * *} \\
(2.24)\end{array}$ & $\begin{array}{c}18.21^{* * *} \\
(0.96)\end{array}$ \\
\hline Black & $\begin{array}{c}19.66^{* * * *} \\
(3.29)\end{array}$ & $\begin{array}{c}21.30^{* * *} \\
(2.88)\end{array}$ & $\begin{array}{c}33.15^{* * *} \\
(2.04)\end{array}$ \\
\hline Hispanic & $\begin{array}{c}3.14 \\
(4.59)\end{array}$ & $\begin{array}{c}7.55 \\
(4.84)\end{array}$ & $\begin{array}{l}-1.90 \\
(4.50)\end{array}$ \\
\hline Other Race & $\begin{array}{l}5.79^{*} \\
(2.70)\end{array}$ & $\begin{array}{c}23.74^{* * *} \\
(5.83)\end{array}$ & $\begin{array}{c}23.11^{* * * *} \\
(3.98)\end{array}$ \\
\hline Asian & $\begin{array}{c}-14.96^{*} \\
(5.88)\end{array}$ & $\begin{array}{l}-0.70 \\
(4.31)\end{array}$ & $\begin{array}{c}-25.04^{* * *} \\
(4.50)\end{array}$ \\
\hline Rural & $\begin{array}{l}-0.52 \\
(0.88)\end{array}$ & $\begin{array}{c}13.38^{* * * *} \\
(3.15)\end{array}$ & $\begin{array}{c}11.91^{* * * *} \\
(2.37)\end{array}$ \\
\hline State Fixed Effects & $X$ & $X$ & $X$ \\
\hline Year Fixed Effects & $X$ & $\mathrm{X}$ & $X$ \\
\hline Family Size Fixed Effects & $\mathrm{X}$ & $\mathrm{X}$ & $\mathrm{X}$ \\
\hline Observations & 117,219 & 117,219 & 117,219 \\
\hline
\end{tabular}

Observed levels of household benefit receipt (outcome variable) refer to the total value of the program's benefits that the household received in the reference year, divided by 12 to provide an average monthly amount. Sample includes households headed by a single female without a college degree between the ages of 18 and 44 . Standard errors in parentheses. ${ }^{*} p<0.05,{ }^{* *} p<0.01,{ }^{* * *} p<0.001$. 
Table 3: Two-Stage Least-Squares Estimation of Policy-Induced Changes in TANF Benefit Allocations on SSI \& SNAP Benefit Allocations

\begin{tabular}{lccc}
\hline & $\begin{array}{c}\text { Monthly SSI } \\
\text { Benefits }\end{array}$ & $\begin{array}{c}\text { Monthly SNAP } \\
\text { Benefits }\end{array}$ & $\begin{array}{c}\text { Monthly SSI + } \\
\text { SNAP Benefits }\end{array}$ \\
\hline Monthly TANF Benefits & $-0.12^{*}$ & $-0.37^{* * *}$ & $-0.49^{* * *}$ \\
& $(0.05)$ & $(0.04)$ & $(0.08)$ \\
Demographic Controls & $\mathrm{X}$ & $\mathrm{X}$ & $\mathrm{X}$ \\
State Controls & $\mathrm{X}$ & $\mathrm{X}$ & $\mathrm{X}$ \\
State Fixed Effects & $\mathrm{X}$ & $\mathrm{X}$ & $\mathrm{X}$ \\
Year Fixed Effects & $\mathrm{X}$ & $\mathrm{X}$ & $\mathrm{X}$ \\
Family Size Fixed Effects & $\mathrm{X}$ & $\mathrm{X}$ & $\mathrm{X}$ \\
\hline Observations & 117,219 & 117,219 & 117,219 \\
\hline
\end{tabular}

Standard errors in parentheses. Demographic and state-level controls are identical to those used in prior models (see Table 1, Table 2). Sample includes households headed by a single female without a college degree between the ages of 18 and $44 .{ }^{*} p<0.05,{ }^{* *} p<0.01,{ }^{* * *} p<0.001$. 


\section{APPENDICES}

\section{Appendix A: Calculation \& Trends in Simulated TANF Generosity}

We largely follow Hoynes and Luttmer (2010) and Hoynes and Patel (2015) in calculating our simulated TANF generosity variable. We define 'generosity' as a combination of the level of potential TANF cash benefits and the income eligibility criteria used to define who can gain access to TANF benefits in a given state and year.

We first determine whether each household meets the income eligibility criteria given the household's respective state, year, and family size. Importantly, we only assess income eligibility and not eligibility rules relating to asset tests, lifetime time limits, work requirements, drug testing, or other parameters that may vary across state and time. Income eligibility criteria are derived from the Urban Institute's Welfare Rules Databook and Database (2015). If the household's gross and/or net income exceed the eligibility cutoff in the respective state and year, we deem it ineligible and set its simulated TANF benefit to zero. Among income-eligible households, the TANF benefit formula is then applied as follows:

$$
\mathrm{B}=\mathrm{M}-\mathrm{P} *(\mathrm{I}-\mathrm{D})
$$

where $\mathrm{B}$ is the calculated TANF benefit level; $\mathrm{M}$ is the maximum TANF benefit level given the state, year, and family size; $\mathrm{I}$ is the net countable income (market wages and unearned income) for benefit calculation purposes; $\mathrm{P}$ is the relative earnings disregard (a share of net countable income that goes uncounted for benefit calculation purposes); and D is the flat earnings disregard (a dollar value that goes uncounted in benefit calculation purposes).

As described in the paper, we estimate the mean benefit level for each state, year, and familysize cluster, then merge the mean benefit value back into our primary dataset matching based on the cluster to which each household belongs. The table below summarizes the key steps in the benefit calculation process. The figures below depict trends in the simulated TANF generosity variable over time by family type, as well as state- and region-level changes over time. 
Table A1: Summary of TANF benefit generosity calculation

\begin{tabular}{|c|c|}
\hline Aim: & Procedure: \\
\hline $\begin{array}{l}\text { 1. Create identical sample of } \\
\text { single mothers for the } \\
\text { calculation of each state- } \\
\text { year's TANF generosity } \\
\text { Purpose: Using an identical } \\
\text { sample for each state-year } \\
\text { ensures that differences in } \\
\text { our simulated TANF } \\
\text { generosity variable are due } \\
\text { to policy differences only, } \\
\text { and not differences in } \\
\text { demographic composition } \\
\text { across state or year }\end{array}$ & $\begin{array}{l}\text { 1. Open sample of single mothers in } 1997 \text { sample of the CPS } \\
\text { ASEC (first year of our analysis) } \\
\text { 2. Create an identical copy of the sample for each subsequent } \\
\text { year of analysis ( } 1998,1999,2000, \ldots, 2015) \text {. For each year, } \\
\text { we now have the same exact sample of single mothers, with } \\
\text { the only difference being the years ( } 1997 \text { through 2015) } \\
\text { attached to the sample. } \\
\text { 3. Convert household income values of each of the replicated } \\
\text { samples ( } 1998 \text { to } 2015 \text { versions of sample) from } 1997 \text { USD } \\
\text { to current dollars. We now have the same sample of single } \\
\text { mothers for each year from } 1997 \text { to } 2015 \text { with the only } \\
\text { difference in the } 19 \text { samples being the inflation adjustments } \\
\text { in household incomes. } \\
\text { 4. For each year of the replicated sample (described above), } \\
\text { perform steps } 5 \text { through } 7 \text {, below, for each state and } \\
\text { Washington, DC: }\end{array}$ \\
\hline $\begin{array}{l}\text { 2. Calculate TANF } \\
\text { generosity in each state-year } \\
\text { Purpose: On the identical } \\
\text { samples of single mothers, } \\
\text { we calculate generosity for } \\
\text { each state-year in a manner } \\
\text { that takes into account } \\
\text { income eligibility thresholds, } \\
\text { earned income disregards, } \\
\text { and maximum TANF benefit } \\
\text { values }\end{array}$ & $\begin{array}{l}\text { 5. Assume that the entire sample of single mothers, described } \\
\text { above, lives in the respective state. Use the given state-year's } \\
\text { TANF policy parameters from the Urban Institute's Welfare } \\
\text { Rules Database to calculate income eligibility for each } \\
\text { single-mother household, taking into account earned income } \\
\text { disregards for purpose of eligibility determination } \\
\text { 6. Among eligible households in the given state-year, } \\
\text { calculate the benefit value that household would receive } \\
\text { given household size, TANF maximum benefit values, and } \\
\text { earned income disregards. } \\
\text { 7. Compute the average TANF benefit value for each 'year- } \\
\text { state-household size' cluster ( } 19 \text { years * } 51 \text { states * } 4 \\
\text { household sizes }=3,876 \text { clusters) in real USD. Export this } \\
\text { data and merge back into the sample being used to estimate } \\
\text { effects of TANF generosity on SNAP/SSI benefit allocations. }\end{array}$ \\
\hline
\end{tabular}


Figure A1: Trends in mean simulated monthly TANF generosity (2014 USD) values by number of children in household (1997 to 2015)

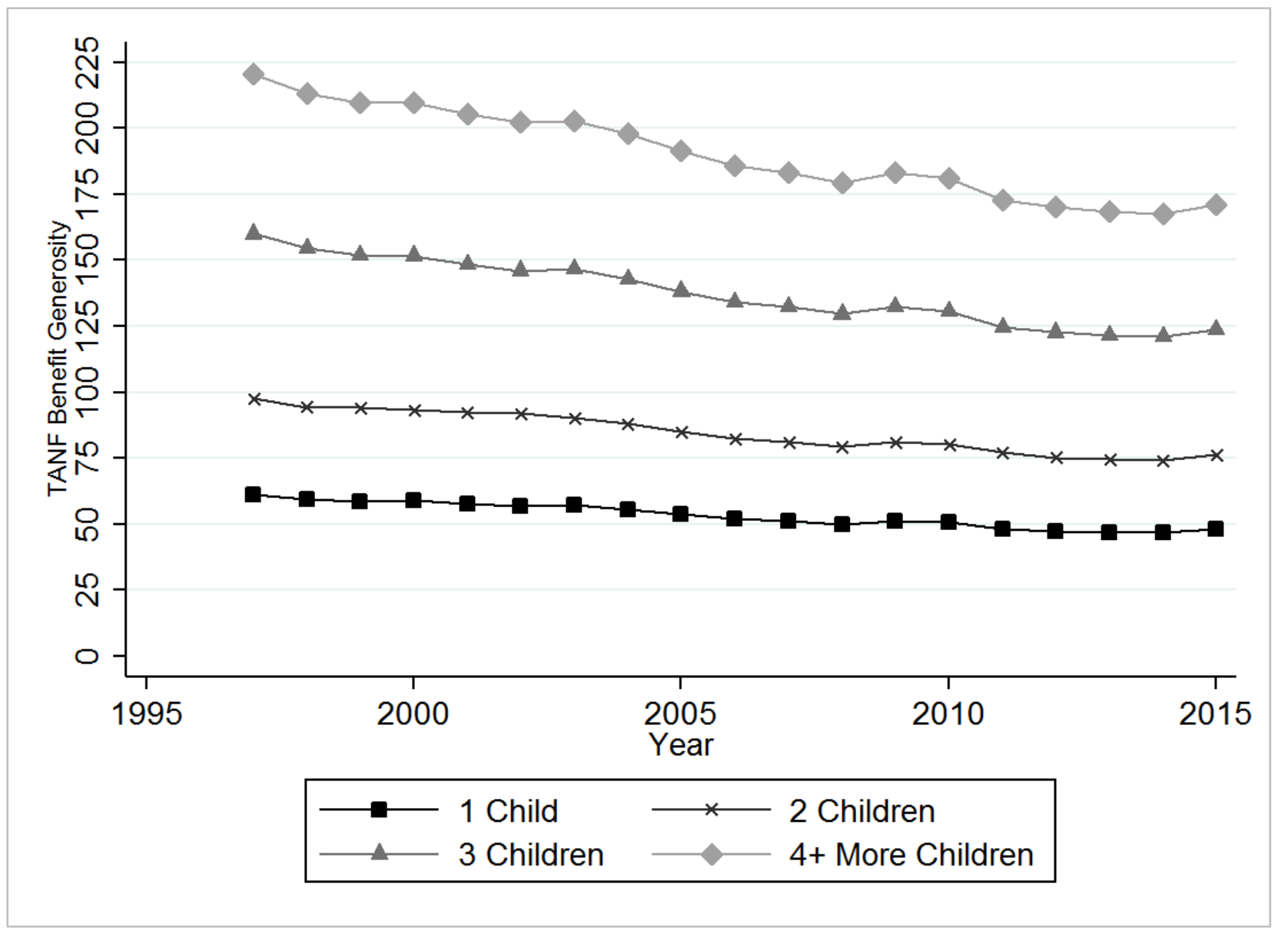


Figure A2: Trends in mean simulated monthly TANF generosity (2014 USD) values by region: Northeast

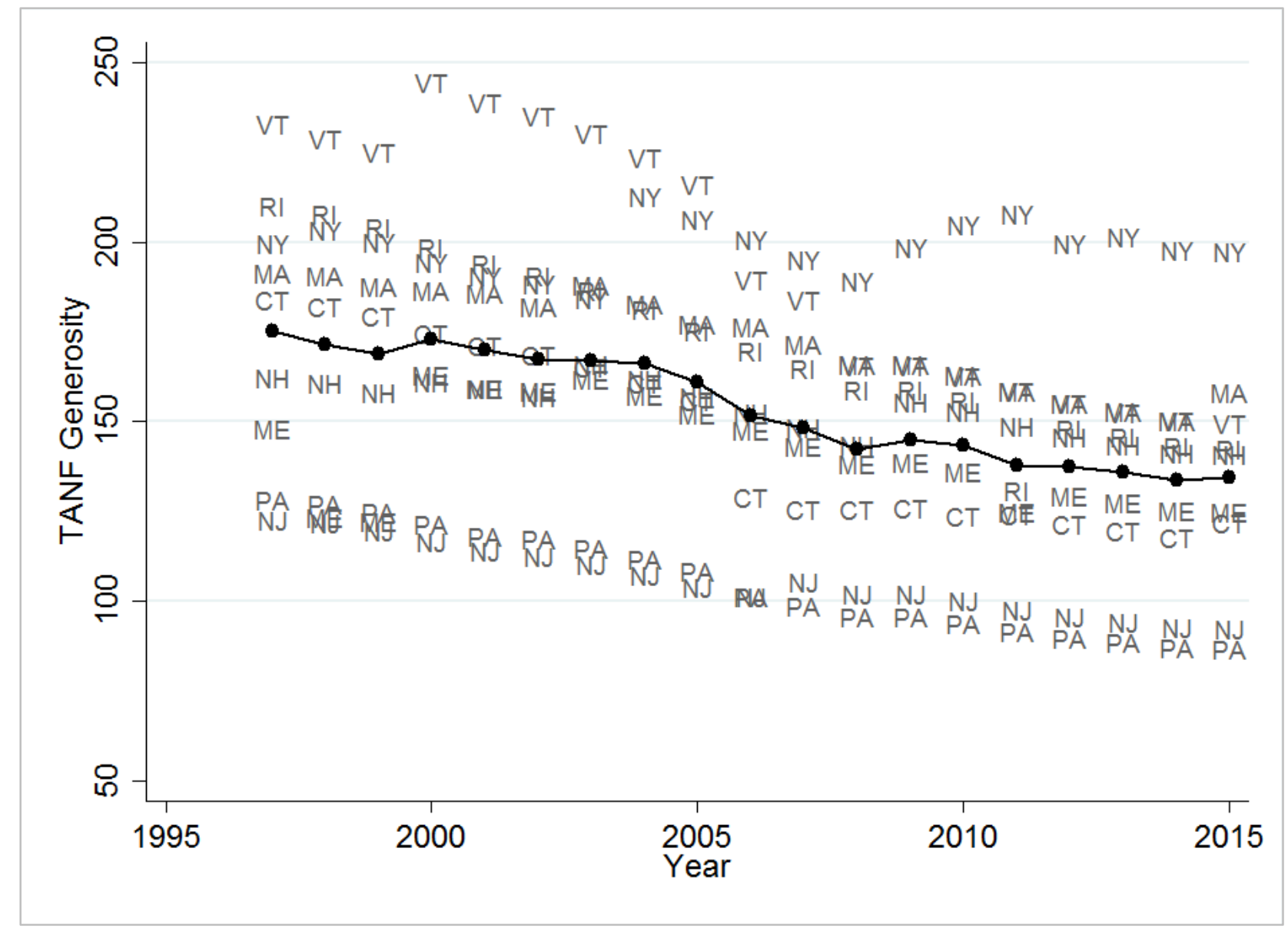

Note: Y-axis begins at 50. States in Northeast include CT, ME, MA, NH, RI, VT, NJ, NY, PA. Dotted black line represents mean value of region-year. 
Figure A3: Trends in mean simulated monthly TANF generosity (2014 USD) values by region: Midwest

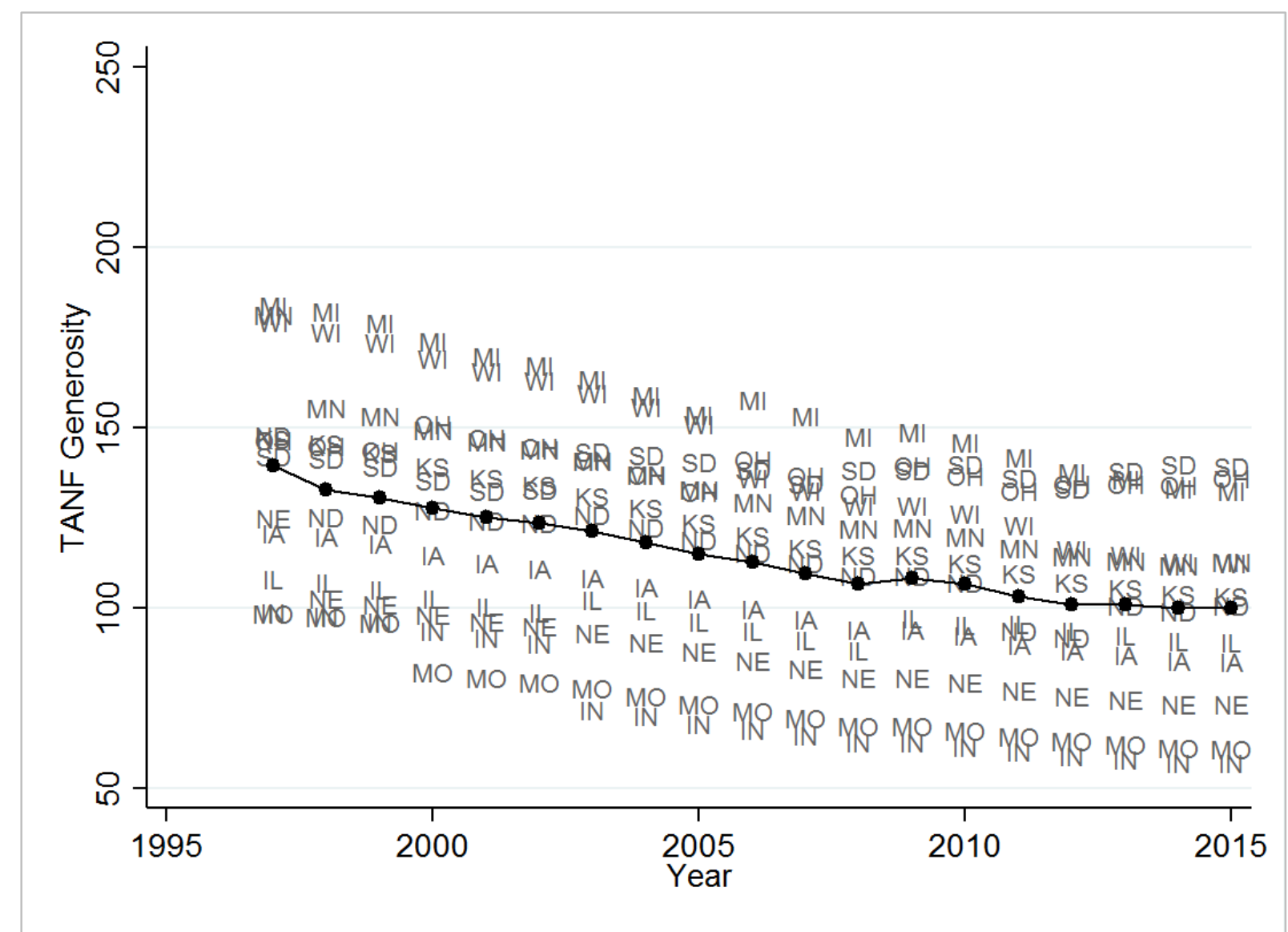

Note: Y-axis begins at 50. States in Midwest include IL, IN, MI, OH, WI, IA, KS, MN, MO, NE, ND, SD. Dotted black line represents mean value of region-year. 
Figure A4: Trends in mean simulated monthly TANF generosity (2014 USD) values by region: South

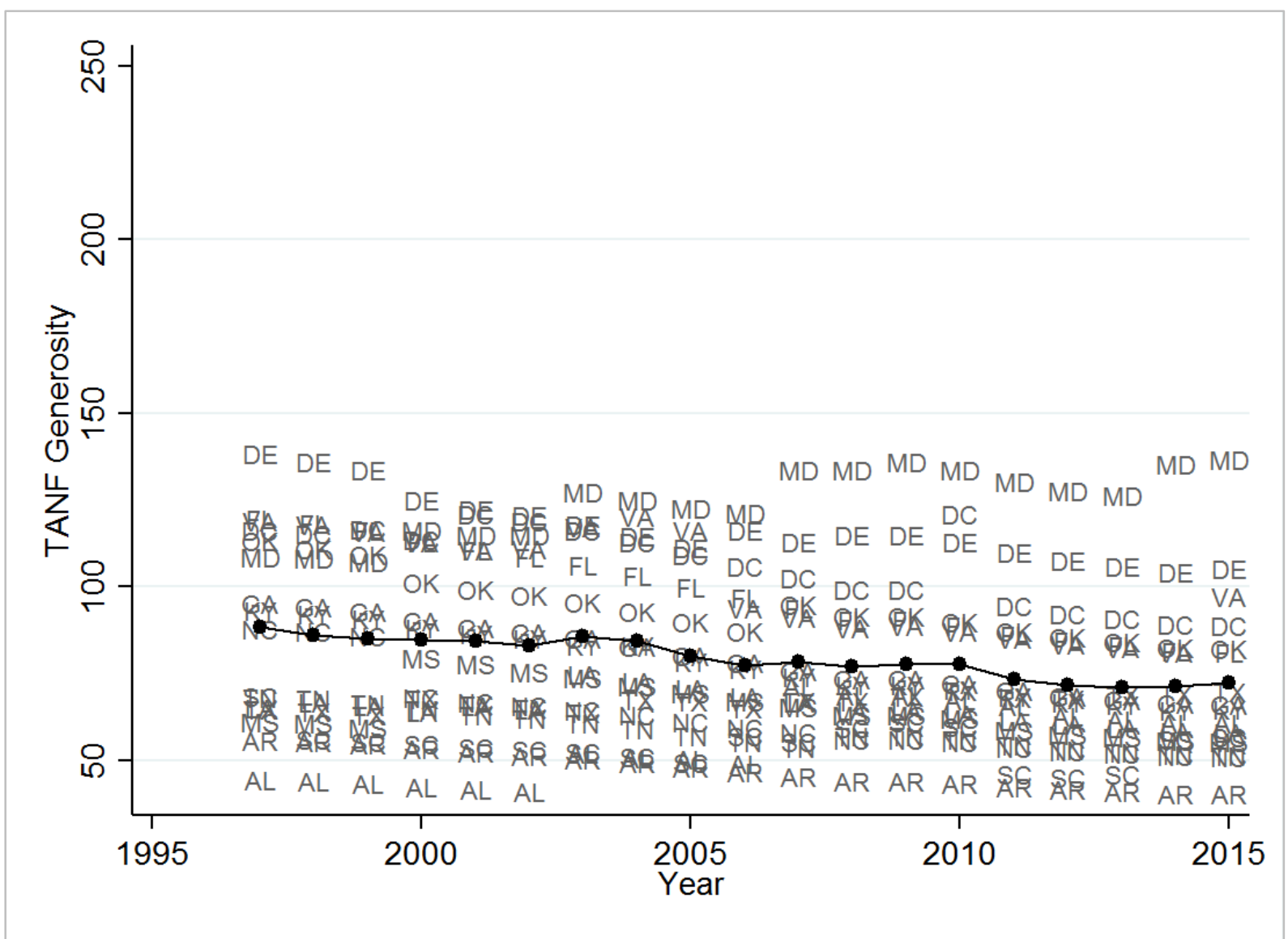

Note: Y-axis begins at 50. States in South include DE, DC, FL, GA, MD, SC, NC, VA, WV. Dotted black line represents mean value of region-year. 
Figure A5: Trends in mean simulated monthly TANF generosity (2014 USD) values by region: West

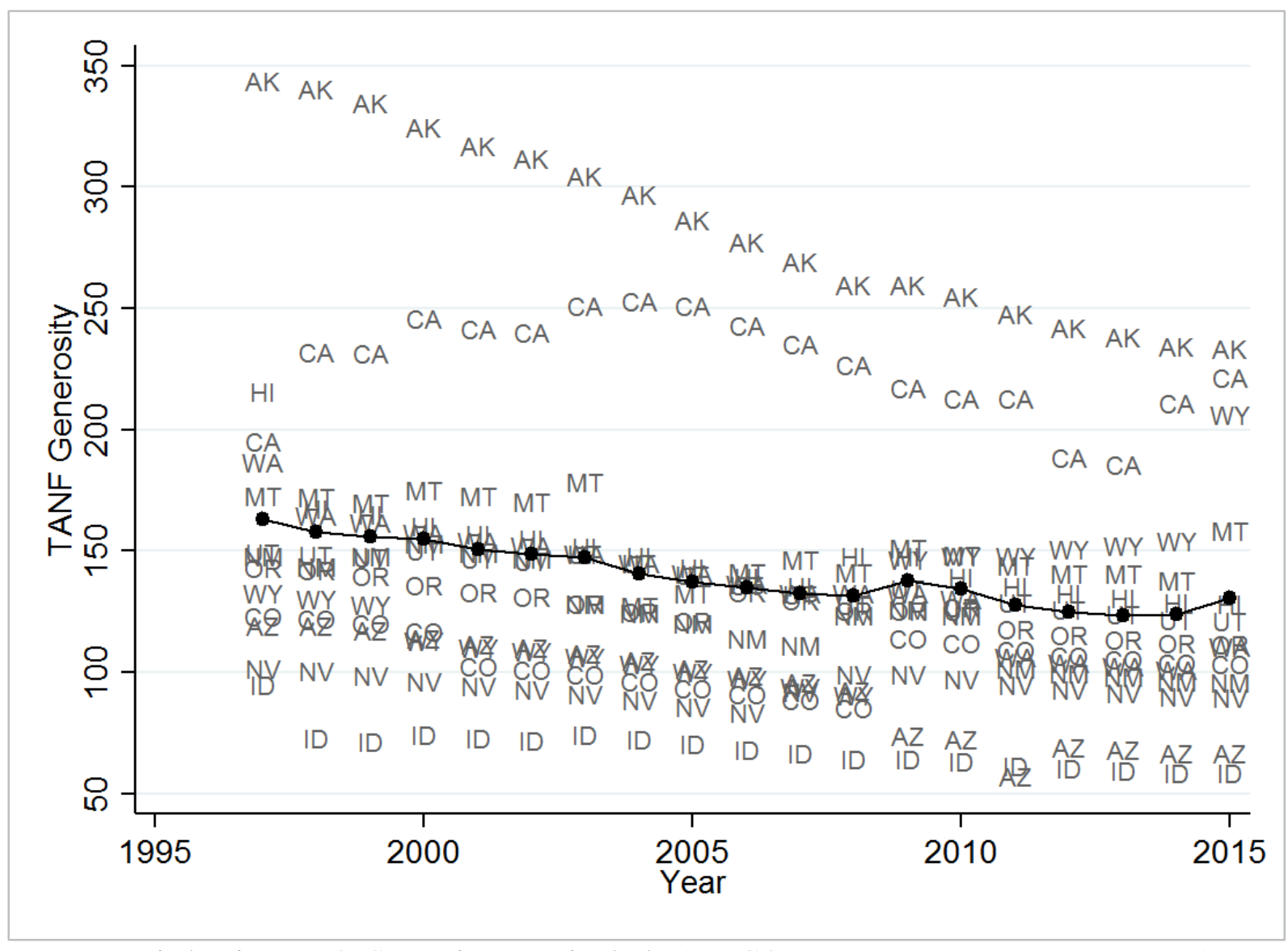

Note: Y-axis begins at 50. States in West include AZ, CO, ID, MT, NV, NM, UT, WY, AK, CA, HI, OR, WA. Dotted black line represents mean value of region-year. 
Appendix B: Two-Stage Least-Squares Estimation of Policy-Induced Changes in TANF Benefit Receipt on SSI \& SNAP Benefit Values using Uncorrected CPS ASEC Data (1997-2015)

\begin{tabular}{lccc}
\hline & $\begin{array}{c}\text { Monthly SSI } \\
\text { Benefits }\end{array}$ & $\begin{array}{c}\text { Monthly SNAP } \\
\text { Benefits }\end{array}$ & $\begin{array}{c}\text { Monthly SSI + } \\
\text { SNAP Benefits }\end{array}$ \\
\hline Monthly TANF Benefits & -0.09 & $-0.35^{* * *}$ & $-0.44^{* * *}$ \\
& $(0.05)$ & $(0.07)$ & $(0.10)$ \\
Demographic Controls & $\mathrm{X}$ & $\mathrm{X}$ & $\mathrm{X}$ \\
State Controls & $\mathrm{X}$ & $\mathrm{X}$ & $\mathrm{X}$ \\
State Fixed Effects & $\mathrm{X}$ & $\mathrm{X}$ & $\mathrm{X}$ \\
Year Fixed Effects & $\mathrm{X}$ & $\mathrm{X}$ & $\mathrm{X}$ \\
Family Size Fixed Effects & $\mathrm{X}$ & $\mathrm{X}$ & $\mathrm{X}$ \\
\hline Observations & 117,219 & 117,219 & 117,219 \\
\hline
\end{tabular}

Standard errors in parentheses. Demographic and state-level controls are identical to those used in prior models (see Table 1, Table 2). Sample includes households headed by a single female without a college degree between the ages of 18 and $44 .{ }^{*} p<0.05,{ }^{* *} p<0.01,{ }^{* * *} p<0.001$. 
Appendix C: Two-Stage Least-Squares Estimation of Policy-Induced Changes in TANF Benefit Allocations Benefit Values using SNAP Quality Control Data (1997 - 2015)

\begin{tabular}{lc}
\hline & Monthly SNAP Benefits \\
\hline Monthly TANF Benefits & $-0.24^{* *}$ \\
& $(0.08)$ \\
& \\
Demographic Controls & $\mathrm{X}$ \\
State Controls & $\mathrm{X}$ \\
State Fixed Effects & $\mathrm{X}$ \\
Year Fixed Effects & $\mathrm{X}$ \\
Family Size Fixed Effects & 250,050 \\
\hline Observations &
\end{tabular}

Standard errors in parentheses. Demographic and state-level controls are identical to those used in prior models (see Table 1, Table 2). Sample includes households headed by a single female without a college degree between the ages of 18 and $44 .{ }^{*} p<0.05,{ }^{* *} p<0.01,{ }^{* * *} p<0.001$. 
Appendix D: Summary Statistics $(n=117,219)$

\section{Variable}

Less than high school (edu)

Under 25 years old

25 to 34 years old

Black

Hispanic

Other rrace

Asian

Rural

Household size (1, 2, 3, 4, 5+)

$\mathrm{HH}$ received SSI benefits

$\mathrm{HH}$ received SNAP benefits

$\mathrm{HH}$ received TANF benefits

Level of SSI benefits received (HH, monthly, \$2014)

Level of SNAP benefits received (HH, monthly, \$2014)

Level of TANF benefits received (HH, monthly, \$2014)

GDP Per Capita $(\log )$

State union density

State unemployment rate

State minimum wage (real)

Immediate TANF sanctions

TANF time limit less than 60 months

TANF family cap

Maximum SNAP benefits (real)

SNAP Asset Increase

Combined SNAP \& SSI Application

Share of SNAP Recipients with Recertification Periods under Three Months

Share of SNAP Benefits as EBT Payments

Fingerprinting During SNAP Eligibility

SNAP Eligibility Extended to Noncitizens

Simplified SNAP Reporting Procedures

Vehicle Exemption in Asset Test
Mean Std. Dev. Min Max

$\begin{array}{llll}0.54 & 0.50 & 0 & 1 \\ 0.24 & 0.43 & 0 & 1 \\ 0.38 & 0.48 & 0 & 1 \\ 0.25 & 0.43 & 0 & 1 \\ 0.20 & 0.40 & 0 & 1 \\ 0.05 & 0.21 & 0 & 1 \\ 0.03 & 0.16 & 0 & 1 \\ 0.20 & 0.40 & 0 & 1 \\ 2.29 & 1.18 & 1 & 5 \\ 0.10 & 0.31 & 0 & 1 \\ 0.43 & 0.50 & 0 & 1 \\ 0.13 & 0.33 & 0 & 1\end{array}$

$\begin{array}{llll}66.56 & 228.24 & 0 & 3979.5\end{array}$

$\begin{array}{llll}129.69 & 205.97 & 0 & 2170.5\end{array}$

$\begin{array}{llll}42.38 & 142.09 & 0 & 1098.9\end{array}$

$\begin{array}{llll}10.75 & 0.23 & 10.25 & 12.061\end{array}$

$\begin{array}{llll}12.17 & 6.08 & 2 & 26.9\end{array}$

$\begin{array}{llll}5.95 & 2.02 & 2.3 & 13.7\end{array}$

$\begin{array}{llll}7.50 & 0.78 & 5.145 & 10.49\end{array}$

$\begin{array}{llll}0.36 & 0.48 & 0 & 1\end{array}$

$\begin{array}{llll}0.16 & 0.36 & 0 & 1\end{array}$

$\begin{array}{rrrr}0.43 & 0.49 & 0 & 1\end{array}$

$\begin{array}{llll}380.74 & 177.13 & 171.8 & 1359.6\end{array}$

$\begin{array}{llll}0.31 & 0.46 & 0 & 1\end{array}$

$\begin{array}{llll}0.23 & 0.42 & 0 & 1\end{array}$

$\begin{array}{llll}0.09 & 0.21 & 0 & 0.8894\end{array}$

$\begin{array}{llll}0.88 & 0.31 & 0 & 1\end{array}$

$\begin{array}{llll}0.18 & 0.38 & 0 & 1\end{array}$

$\begin{array}{llll}0.15 & 0.36 & 0 & 1\end{array}$

$\begin{array}{llll}0.62 & 0.48 & 0 & 1\end{array}$

$\begin{array}{llll}0.50 & 0.50 & 0 & 1\end{array}$ 